\title{
Origin of fabric-selective dolomitization recognizable in the field: two case studies from Anisian carbonate rocks in the western Balkanides
}

\author{
Athanas Chatalov \\ Sofia University “St Kliment Ohridski”, 15 Tsar Osvoboditel Blvd, 1504 Sofia, Bulgaria; e-mail: chatalov@gea.uni-sofia.bg \\ (Accepted in revised form: March 2018)
}

\begin{abstract}
The origin of dolomitized burrows (Cruziana ichnofacies) in limestones and dolomitic layers in limestone-dolostone ribbon rocks was studied on the basis of petrography, X-ray diffractometry, geochemical data and isotope signatures of the dolomites. Selective dolomitization of the burrows with a local source of $\mathrm{Mg}$ occurred in a near-surface setting from non-evaporitic solutions with low $\mathrm{Mg} / \mathrm{Ca}$ ratio. The low-temperature precipitation of non-stoichiometric (with Ca excess) dolomite was microbially mediated and controlled by bacterial sulphate reduction. The carbon for dolomite formation was largely derived from seawater and/or dissolution of precursor carbonate sediments, and partly derived from the decomposition of organic matter. Selective dolomitization of primarily argillaceous carbonate layers in the ribbon rocks was mainly associated with an autochthonous source of Mg. Clay mineral transformations (i.e., illitization of smectite) at intermediate burial depths supplied Mg ions for the formation of Ca-rich (locally ferroan) dolomite. However, differential diagenesis of the originally clay-rich and clay-poor layers may also have favoured early dolomite precipitation, whereupon contemporaneous seawater was the primary Mg source during shallow burial. The obtained results show that various factors control the formation of fine-grained, non-stoichiometric dolomite with macroscopically recognizable fabric-selective character of replacement.
\end{abstract}

Chatalov, A. 2018. Origin of fabric selective dolomitization recognizable in the field: two case studies from Anisian carbonate rocks in the western Balkanides. Geologica Balcanica 47 (1), 43-60.

Keywords: dolomitization, fabric-selective, burrows, ribbon rocks, Middle Triassic, western Balkanides.

\section{INTRODUCTION}

Formation of dolomite and dolomitization patterns in carbonate rocks are controlled by several factors, including precursor mineralogy and grain/crystal size, porosity, permeability, source of $\mathrm{Mg}$, character and delivery mechanism of the dolomitizing fluids, temperature, microbial activity, multiple dolomitization events, and recrystallization (e.g., Murray and Lucia, 1967; Sibley, 1982; Bullen and Sibley, 1984; Mazzullo, 1992, 2000; Purser et al., 1994; Machel, 1997, 2004; Warren, 2000; Armenteros, 2010; Gregg et al., 2015; Ren and Jones, 2017). In certain cases, the resultant dolomite distribution clearly indicates selectivity with respect to former lithologies and textural components on macroscopic or microscopic scale. Examples of fabric-selective dolomitization recognizable in the field comprise dolomitic burrows, mottles, veins, layers in ribbon rocks, laminae in stromatolites, and dolomitized matrix in carbonate breccias/ conglomerates and nodular beds (e.g., Gebelein and Hoffman, 1973; Morrow, 1978; Coniglio and James, 1988; Jones et al., 1979; McHargue and Price, 1982; Demicco and Hardie, 1994; Chow and Longstaffe, 1995; Török, 2000; Dilliard et al., 2010; Sharp et al., 2010; Bertok et al., 2011; Bayet-Goll et al., 2015; Barale et al., 2016).

This study is focused on two different types of selective dolomitization, which have been recognized macroscopically in Anisian carbonate rocks from Northwest Bulgaria. Dolomitized burrows in limestones and dolomitic layers in ribbon rocks were investigated on the basis of petrographic observations, XRD analysis, geochemical data and isotope signatures of the dolomites. The obtained results are used to interpret the origin of dolomitization in terms of relative timing, diagenetic setting, source of $\mathrm{Mg}$, precursor mineralogy, character of the dolomitizing fluids, general temperature conditions, biological influence, and consequent alteration during burial. 


\section{GEOLOGICAL SETTING}

The Triassic sedimentary rocks exposed in NW Bulgaria have been assigned to the Balkanide (facies) type of Triassic (Ganev, 1974; Chatalov, 1980). Lithostratigraphically, the Lower to Upper Triassic marine strata have been referred to as the Iskar Carbonate Group (Tronkov, 1981). This unit has maximum thickness of about $500 \mathrm{~m}$ and consists of limestones, dolostones, and minor amounts of siliciclastic rocks. The Iskar Carbonate Group overlies red-bed deposits of the Lower Triassic Petrohan Terrigenous Group (Tronkov, 1981) and is covered by variegated siliciclastic and carbonate deposits of the Upper Triassic Moesian Group (Chemberski et al., 1974). The entire Triassic succession corresponds to a symmetrical second-order transgressive-regressive (T-R) stratigraphic cycle (Chatalov, 2013a). According to the Alpine tectonic model for Bulgaria proposed by Ivanov (2017), the Triassic rocks are exposed in the West Balkan Zone of the External Balkanides.

Biostratigraphic and sedimentological studies indicate that marine deposition occurred from the late Olenekian or early Anisian to the early Carnian (Tronkov, 1968, 1973; Ajdanlijsky et al., 2018; see also Chatalov, 2017b) on a homoclinal carbonate ramp with local distal steepening, which evolved in the subtropical belt on the north-western shelf area of the Tethys Ocean (Čatalov, 1988; Chatalov, 2013a, 2018). Two main stages of the ramp development (retrogradational and progradational) produced two genetic units (transgressive and regressive) that are separated by a maximum flooding zone, i.e., Terebratula Beds (Chatalov, 2013a, 2018). Subtidal, intertidal and supratidal facies were formed in several depositional environments of three ramp zones: inner ramp, mid-ramp, and outer ramp (Chatalov, 2013a, 2018; Chatalov et al., 2015). Various environmental constraints of the ramp depositional system and controlling factors on its development have been recognized and thoroughly discussed (Chatalov, 2013a, 2018).

\section{PREVIOUS RESEARCH}

The distribution and petrographic characteristics of dolomitic rocks in the Triassic marine successions from NW Bulgaria have been described by many researchers (e.g., Tronkov, 1960, 1968, 1973; Gnoevaya, 1965; Tronkov et al., 1965; Chatalov, 1999a, 2009; Chatalov and Benatov, 2000; Chatalov and Stefanov, 2013). The presence of dolomitized burrows in the Zimevitsa (Chatalov et al., 2001) and Zgorigrad members (Tronkov, 1976) of the Anisian Babina Formation (Tronkov, 1968) from outcrops in the Iskar River Gorge was reported by Chatalov et al. (2001) and Chatalov (2013a), respectively. Dolomitized marly matrix in nodular beds and dolomitic layers in ribbon rocks have recently been documented from ex- posures of the Zgorigrad Member in the Vratsa Balkan (Chatalov, 2018).

Results from studies on dolomitization patterns and dolomite origin have been published in several works. First, Tronkov (1983) interpreted dolomicrites in the Opletnya Member (Olenekian-Anisian) of the Mogilata Formation (Tronkov, 1968; Assereto et al., 1983) as chemically precipitated sediments in arid climate. Later, Chatalov $(1994,1997)$ presented petrographic and geochemical evidence for early diagenetic dolomitization of intertidal and supratidal deposits (including the dolomicrites) in the Opletnya Member. The origin of Olenekian and Anisian dolomites from a large area in the western Balkanides was investigated by Chatalov and Stanimirova (2001) on the basis of data from X-ray diffractometry. Field observations and laboratory techniques were used by Chatalov (2014) for genetic interpretation of Olenekian to Carnian dolostones exposed in the Elovitsa (Melyane) anticline. Penecontemporaneous dolomitization of Spathian peritidal deposits (Svidol Formation), including mimetic replacement of oolites, was described by Chatalov (1999b) and Chatalov et al. (2015).

\section{MATERIALS AND METHODS}

Field observations across the whole area with exposures of Triassic rocks in NW Bulgaria indicate that macroscopically recognizable selective dolomitization occurs in three lithostratigraphic units: the Opletnya Member, the Zimevitsa Member, and the Zgorigrad Member. These occurrences were studied in six stratigraphic sections from the Berkovitsa unit and Vratsa unit of the West Balkan tectonic zone (Fig. 1). The rock colours, stratification patterns, sedimentary structures, and textures were described, and the dolomitic lithology was tested with $5 \%$ solution of $\mathrm{HCl}$. Forty-two samples were collected from selectively dolomitized burrows and dolomitic layers in ribbon rocks for further laboratory work. In addition, seven samples were taken from limestone layers of the ribbon carbonates.

Standard thin-sections for observation on transmitting light-microscope were prepared from all samples. A staining procedure with combined alizarine red S + potassium ferricyanide solution (Dickson, 1965) was applied to distinguish ferroan and non-ferroan calcite and dolomite phases. The flowchart proposed by Chatalov (2013b) was used for micropetrographic description of the dolostones, and the limestone textures were described, following the classification scheme of Folk (1962).

Fourteen powdered whole-rock samples were analysed by X-ray diffractometry, using TUR M62 diffractometer with filtered Co $\mathrm{K}_{\mathrm{a}}$ radiation under operating conditions of $30 \mathrm{~mA}$ current and $40 \mathrm{kV}$ voltage. The stoichiometry and degree of ordering of non-ferroan dolomite were determined by applying the standard techniques described by Chatalov and Stanimirova (2001) and Chatalov (2014). The samples were 


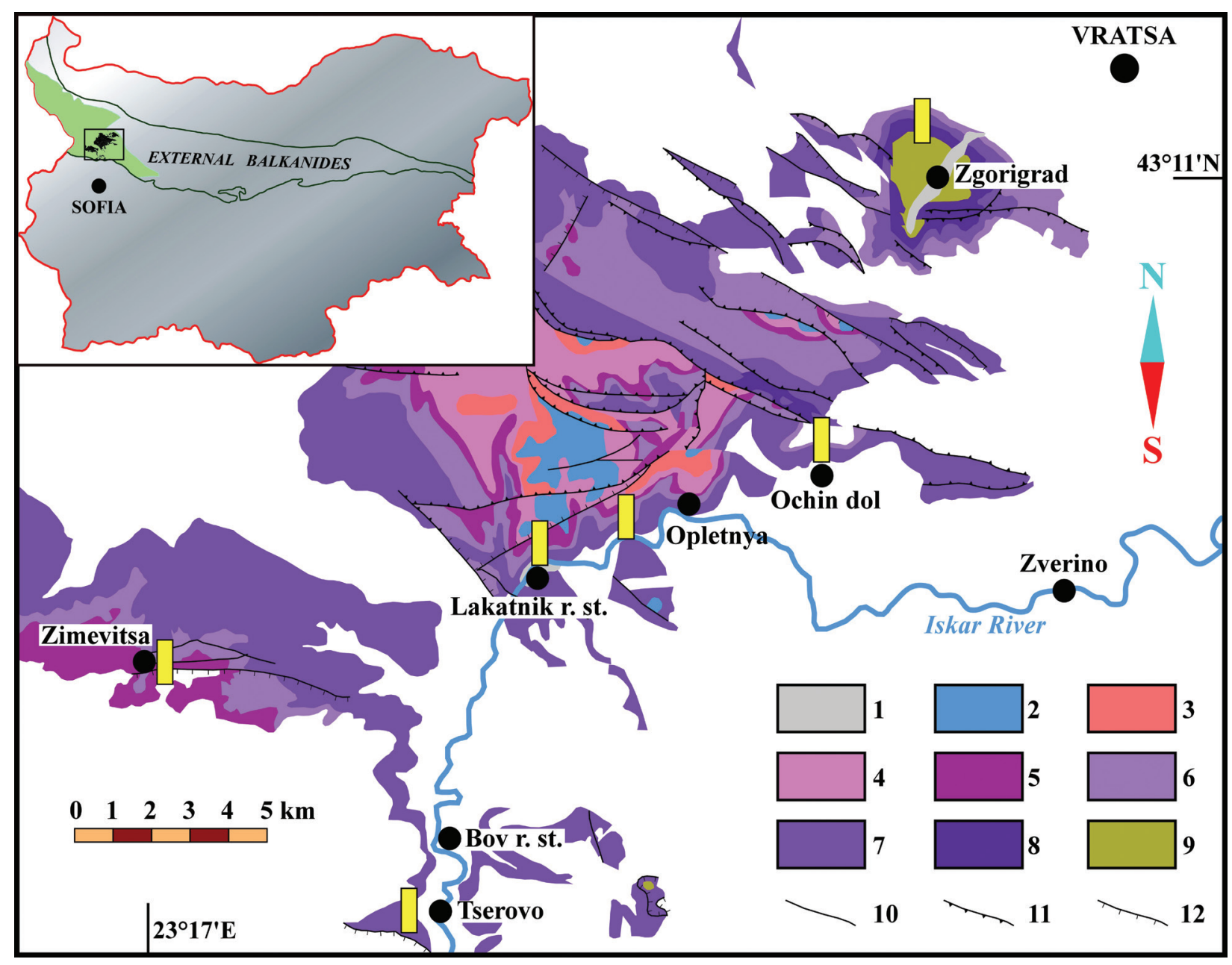

Fig. 1. Exposures of the Iskar Carbonate Group (Lower-Upper Triassic) in parts of the Berkovitsa Unit and the Vratsa Unit of the West Balkan tectonic zone (data used from Tzankov et al., 1991; Angelov et al., 1992). Legend: 1 - Quaternary sediments, 2 - Jurassic rocks, 3 - Moesian Group (Carnian-Norian?), 4 - Rusinovdel Formation (Ladinian-Carnian), 5 - Milanovo Formation (Anisian-Ladinian), 6 - Babina Formation (Anisian), 7 - Mogilata Formation (Olenekian-Anisian) and Svidol Formation (Olenekian), 8 - Petrohan Terrigenous Group (Lower Triassic), 9 - Permian rocks, 10 - normal fault, 11 - reverse fault, 12 - thrust. Rectangles show location of the studied sections. Inset map: green - West Balkan Zone. The Alpine tectonic subdivision of Bulgaria is after Ivanov (2017).

scanned in the $4-80^{\circ} 2 \theta$ range with step size $0.02^{\circ}$ aiming to detect the presence of other minerals (e.g., clays).

Twelve powdered samples from the ribbon carbonates were reacted with $10 \% \mathrm{HCl}$ (for the dolostones) and $5 \% \mathrm{HCl}$ (for the limestones) to determine the acid insoluble residue. The same samples were also treated by classical chemical methods to analyse the $\mathrm{Al}$ content. For this purpose, they were dissolved in $\mathrm{HClO}_{4}+\mathrm{HF}$ and $\mathrm{Al}$ was determined from the obtained solution by complexometric titration.

Six powdered whole-rock samples were analysed for $\delta^{18} \mathrm{O}$ and $\delta^{13} \mathrm{C}$ of dolomite by using a method modified from McCrea (1950) and Rosenbaum and Sheppard (1986). The samples ( 20 mg) were placed in Pyrex glass vials under vacuum and treated with $100 \%$ solution of $\mathrm{H}_{3} \mathrm{PO}_{4}$ for $45 \mathrm{~min}$ at $25^{\circ} \mathrm{C}$ to remove calcite. Then, the samples were heated at $100{ }^{\circ} \mathrm{C}\left( \pm 1^{\circ} \mathrm{C}\right)$ for
1 hour, and the extracted $\mathrm{CO}_{2}$ was cryogenically purified in vacuum. The $\mathrm{CO}_{2}$ was analysed with Finnigan Mat 253 spectrometer operating in dual inlet mode. The oxygen isotopic composition was corrected with phosphoric acid fractionation factor 1.00913 (Rosenbaum and Sheppard, 1986). The results are expressed in per mille values and reported relative to the V-PDB standard. The analytical precision is $\pm 0.1 \%$ for both isotopes.

\section{PETROGRAPHY}

\section{Dolomitized burrows}

Selectively dolomitized burrows occur in an approximately $10 \mathrm{~m}$ thick interval of the Opletnya Member and also in several discrete beds of the Zimevitsa and 
Zgorigrad members from exposures in the Berkovitsa Unit (Fig. 2). Macroscopically, the burrows are easily recognizable on weathered rock surface by their negative or positive relief and different colours (grey-yel- lowish, beige, ochre, rusty) in the background of the light to dark grey micritic limestones (Fig. $3 a-f$ ). The dolomitized trace fossils have various lengths (from $<1 \mathrm{~cm}$ to $12 \mathrm{~cm}$ ), widths (from several $\mathrm{mm}$ to $1.6 \mathrm{~cm}$ ),

\section{section Sfrazhen}

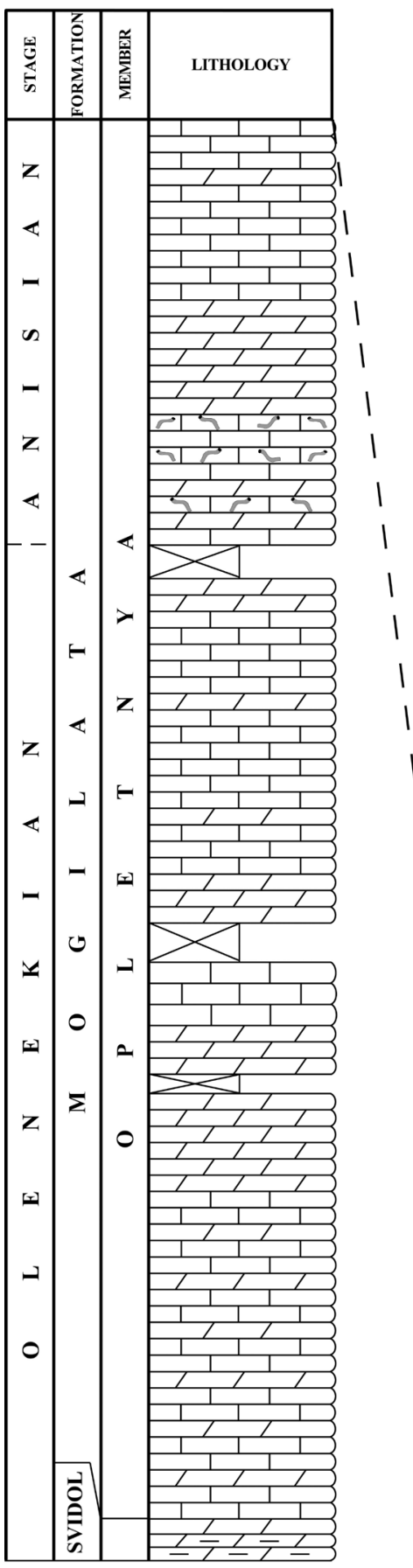

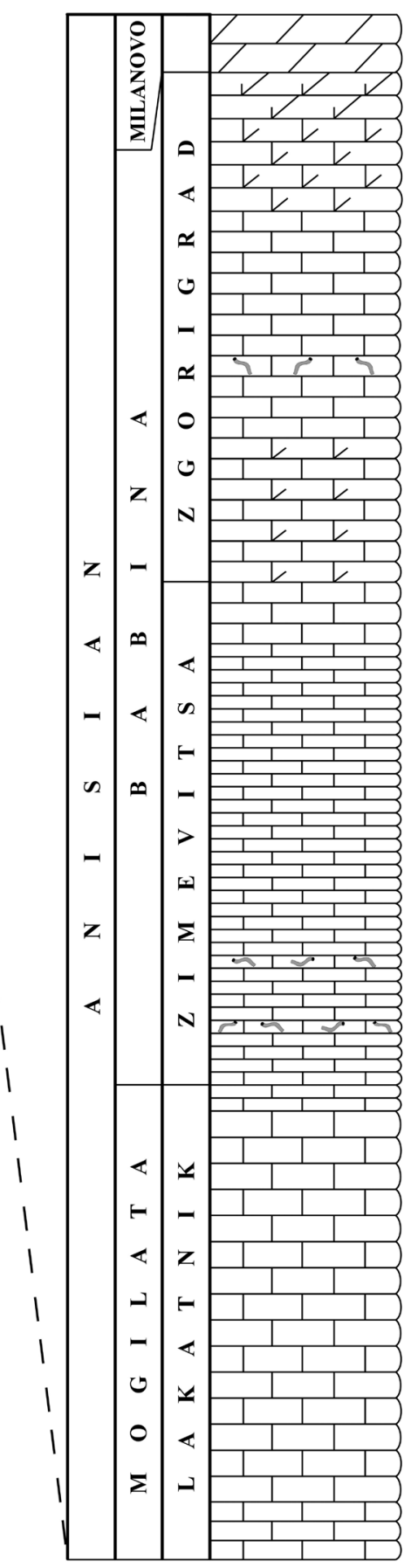

m

50

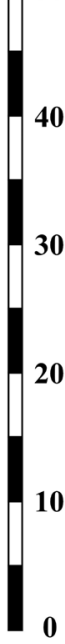

\section{section Zgorigrad}

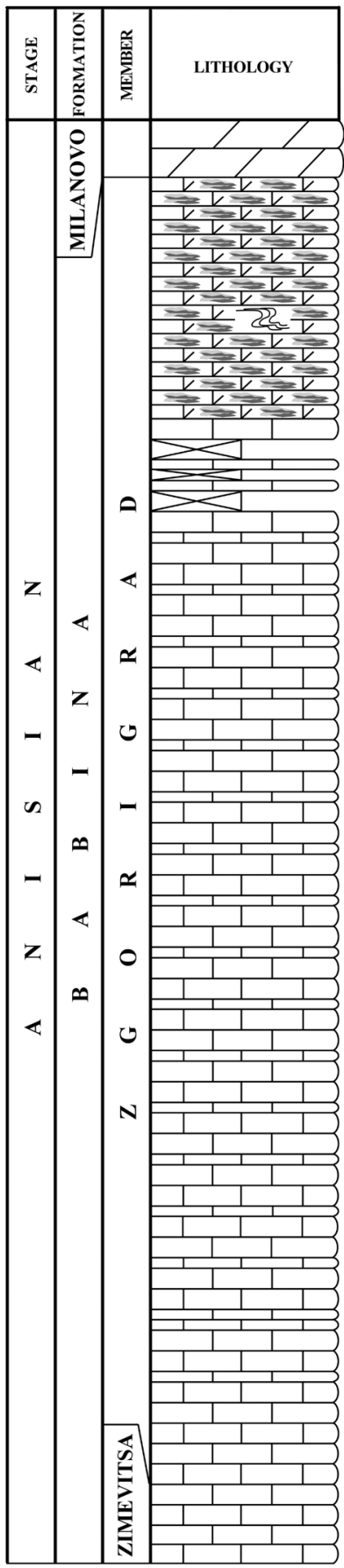

\section{7 dolostone \\ $-\bar{T}$ dolomitic marl}

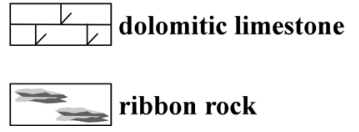

$\square_{1}$ limestone

ख्टि slump

Fig. 2. Vertical distribution of the macroscopically recognizable occurrences of fabric-selective dolomitization. 
morphology (straight, curved, meandering, irregular, branched, U-shaped, Y-shaped), orientation (subhorizontal, inclined, subvertical), and cross-section (circular or elliptical). The burrows are mostly isolated but may locally be interconnected to form a dense network in the rock. In some cases, predominantly subvertical burrows are developed below submarine discontinuities (Clari et al., 1995) resulting from breaks in sedimentation (i.e., marine omission surfaces).

In thin-sections, the host limestones show diverse textures (micrite, fossil-bearing micrite, biomicrite, pelintramicrite, or biointraoncomicrite), while the bur-
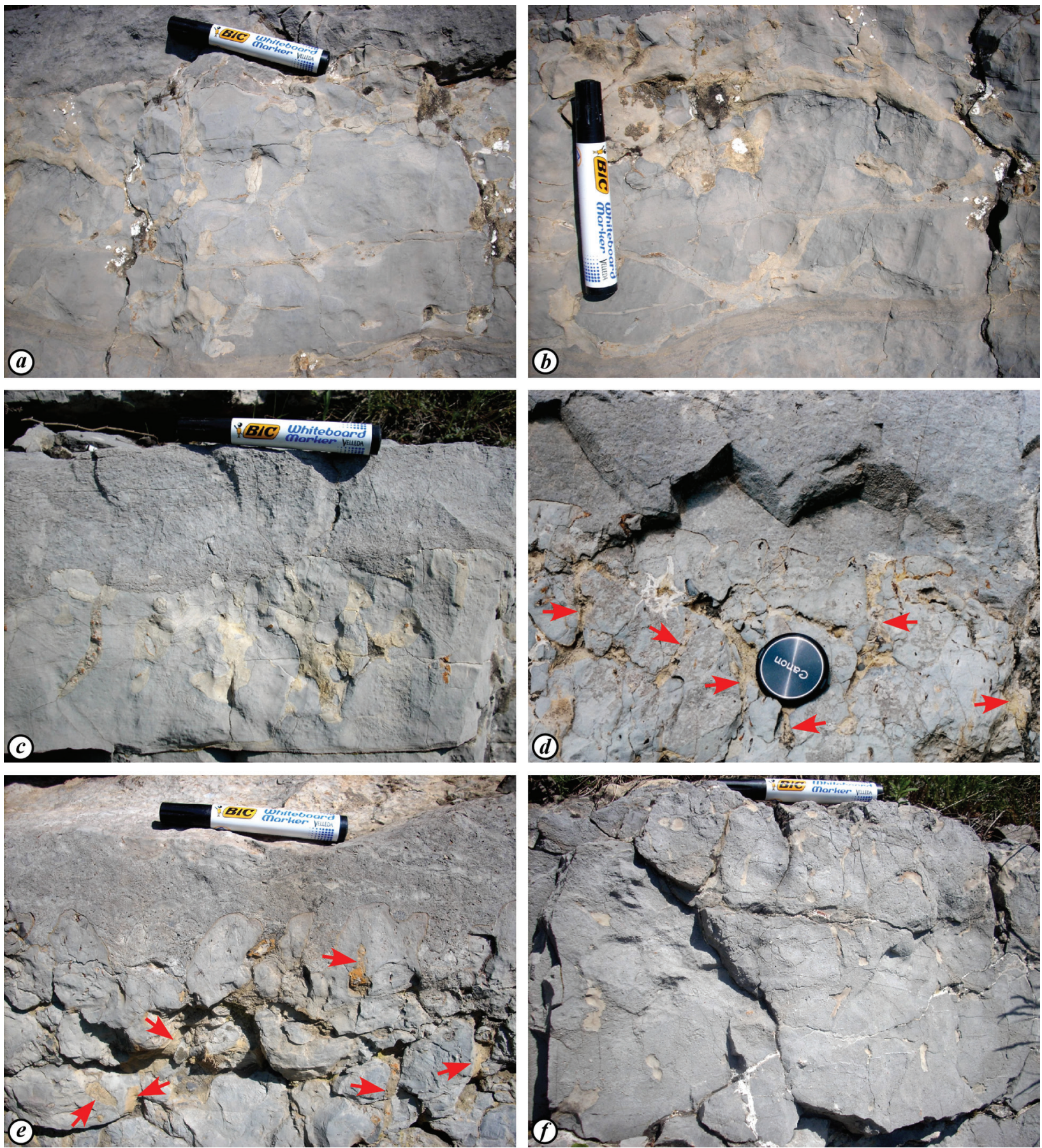

Fig. 3. Selectively dolomitized burrows in micritic limestones of the Opletnya Member $(a-c)$, the Zimevitsa Member $(d, e)$, and the Zgorigrad Member $(f): a, b$ ) isolated and interconnected burrows showing pale ochre colour and positive relief, as well as various length, width, morphology, and orientation; $c$ ) burrows developed below submarine discontinuity surface (firmground); $d, e$ ) inclined to vertical, beige to rusty-coloured burrows with negative relief (arrows); $f$ ) isolated, yellowish-grey burrows with negative relief, showing various sizes and shapes. 
row fills have textures of cryptocrystalline $(<4 \mu \mathrm{m})$ to microcrystalline $(4-32 \mu \mathrm{m})$ dolostones. The constantly sharp boundaries between the two lithologies are undulating (Fig. 4a), irregular, or rarely planar. Allochems (intraclasts, fossils, oncoids) in the limestones may be truncated at the contact (Fig. $4 b$ ), and calcitic bioclasts (e.g., bivalves) locally penetrate into the dolomitic burrow fills (Fig. 4c). Some burrows make protrusions into the limestone, which are commonly accompanied by incorporation of non-dolomitized clasts (Fig. $4 d$ ). Concentrations of small $(<0.1 \mathrm{~mm})$, moderately sorted dolomitized peloids (probably faecal pellets), or dark-coloured dolomicritic halos having variable thicknesses (diagenetic halos sensu Gingras et al., 2004; see also Corlett and Jones, 2012) may be observed along the burrow periphery (Fig. $4 e, f$ ). Elsewhere, the contacts with the limestone are delineated by thin streaks of fine-grained pyrite (Fig. 4g), low-amplitude stylolites, or irregular strips of fine crystalline dolomite (Fig. 4h). The burrow fills consist of non-ferroan, predominantly subhedral and euhedral dolomite, while anhedral crystals are locally distinguished. The dolomite mosaics show homogeneous or heterogeneous crystal size (for example, larger euhedral crystals occur in more fine-grained dolomite matrix). The applied staining reactions do not reveal the presence of micritic or microsparitic calcite. Additional fabric features include scarce pyrite crystals, former irregular voids filled with fine to coarse crystalline drusy dolomite, and crosscutting dissolution seams, stylolites and calcite veinlets.

\section{Limestone-dolostone ribbon rocks}

The second type of macroscopically recognizable selective dolomitization occurs in an exposure of the Babina Formation, which is located north of Zgorigrad Village in the Vratsa Unit. An approximately $20 \mathrm{~m}$ thick interval in the uppermost part of the Zgorigrad Member (Fig. 2) includes heterolithic beds of grey limestones and ochre-coloured dolostones (Fig. 5a). The irregularly alternating layers in these ribbon rocks are continuous, lenticular, or pinching-out. They have various thicknesses (from several $\mathrm{mm}$ to $5-6 \mathrm{~cm}$ ) and sharp boundaries (planar, undulating, or irregular) that may be enhanced by stylolites. Dolostone lenses with length up to $13 \mathrm{~cm}$, thickness up to $2 \mathrm{~cm}$ and subparallel orientation to the bedding planes show isolated occurrences in the limestone (Fig. 5b), thus resembling the flaser bedding in siliciclastic deposits (Reineck and Singh, 1980). Massive appearance is typical for both lithologies, but some dolostone layers display faint horizontal lamination, which is locally affected by soft deformation. Many limestone layers are cracked, disrupted, and/or brecciated (Fig. 5c). The vertical or oblique cracks have width of several millimetres and are commonly filled with dolostone material from adjacent layers. Predominantly pebble-sized limestone clasts showing various shapes, degree of roundness and orientation are embedded (i.e., "float") in the dolomitic matrix (Fig. $5 d, e$ ). The faint laminae in some dolostone layers bend around the larger limestone clasts (Fig. 5f).

Under the microscope, the two lithologically different types of layers in the ribbon rocks have mostly sharp boundaries (Fig. 6a). Only locally, scattered dolomite crystals and/or selectively dolomitized clasts occur in the limestone close to the contact (Fig. 6b). The limestone layers show textures of micrite (predominantly) or fossil-bearing micrite (rarely). The dolomite crystal size in the dolostone layers ranges from several $\mu \mathrm{m}$ to $50 \mu \mathrm{m}$, which defines the rocks as cryptocrystalline to extremely fine-crystalline dolostones that are clayey and calcareous to various degrees (Fig. 6c). The presence of brownish clay-sized material is best visible in vertical cracks of the limestone layers where an upwards gradation in the amount of replacive dolomite can be observed (Fig. 6d). The dolomite is non-ferroan and rarely ferroan (Fig. 6e), showing homogeneous or heterogeneous crystal size and euhedral, subhedral, or anhedral crystal shape. The limestone clasts and scarce calcitic bioclasts (crinoids, brachiopods, bivalves) in the dolostone layers may be dolomitized slightly (Fig. 6f, g). Some articulated brachiopod and bivalve shells are crushed as a result of mechanical compaction and filled with dolomite (Fig. 6h). The latter is probably a cement phase as inferred from its larger crystal size and absence of

Fig. 4. Microphotographs of burrow-related dolomite: $a$ ) weakly undulating, sharp boundary between host limestone (ca) and dolomite-filled burrow (do); b) truncated allochems (large arrow) at the contact between dolomitic burrow and surrounding limestone; c) calcitic bivalve shell (large arrow) penetrating into dolomitic burrow fill; $d$ ) non-dolomitized clasts (large arrows) incorporated in dolomitic burrow from the adjacent limestone; $e$ ) small dolomitized peloids (large arrows) concentrated along the periphery of burrow fill; f) dolomicritic halo (large arrows) with variable thickness delineating dolomitized burrow; $g$ ) Contact between host limestone and dolomitic burrow marked by thin streak of fine-grained pyrite (large arrows); $h$ ) fine-crystalline dolomite developed along the periphery of dolomitic burrow. Note: Small red arrows indicate dispersed fine-grained pyrite. All thin-sections are stained and all microphotographs are in plane-polarized light. 

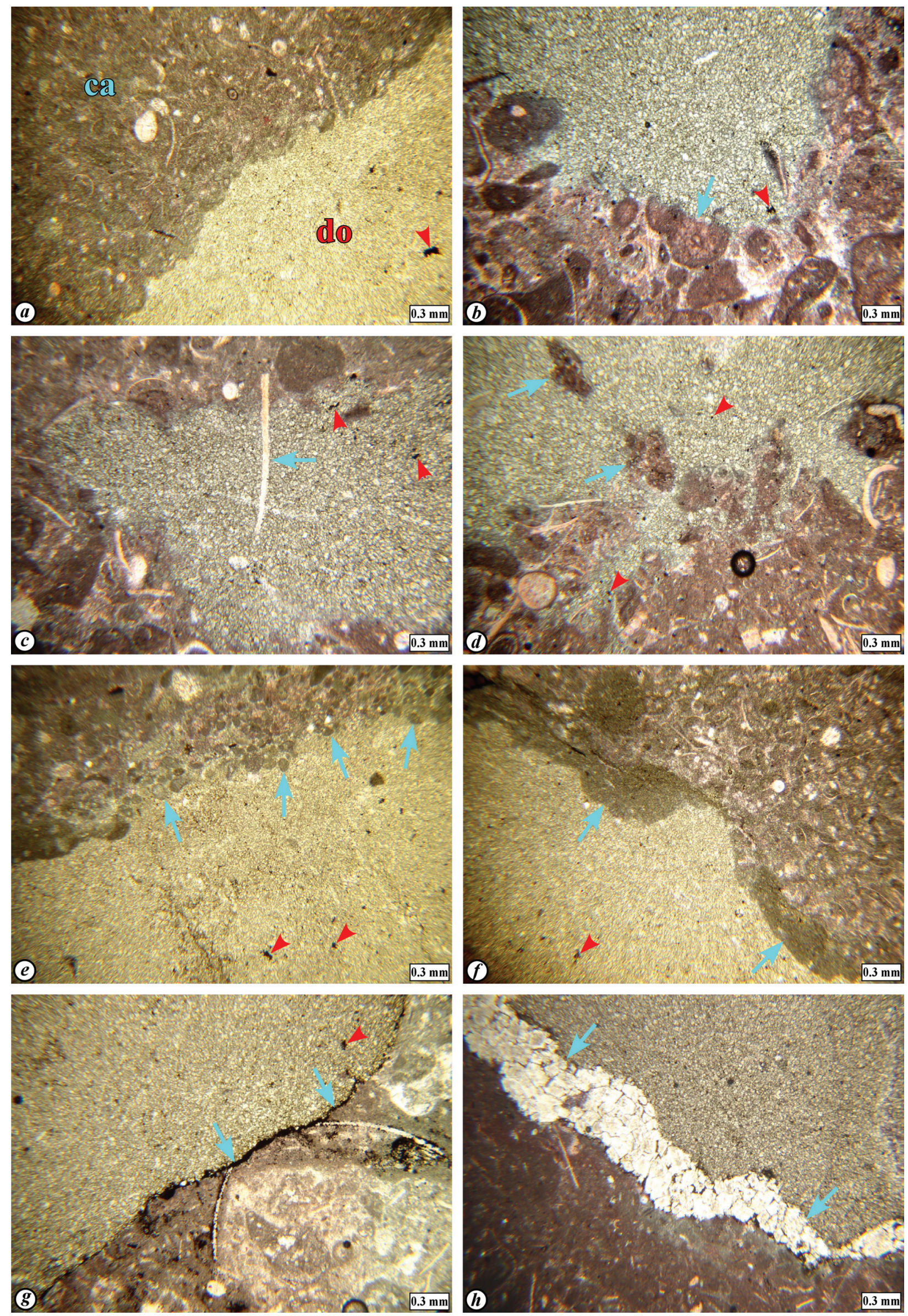

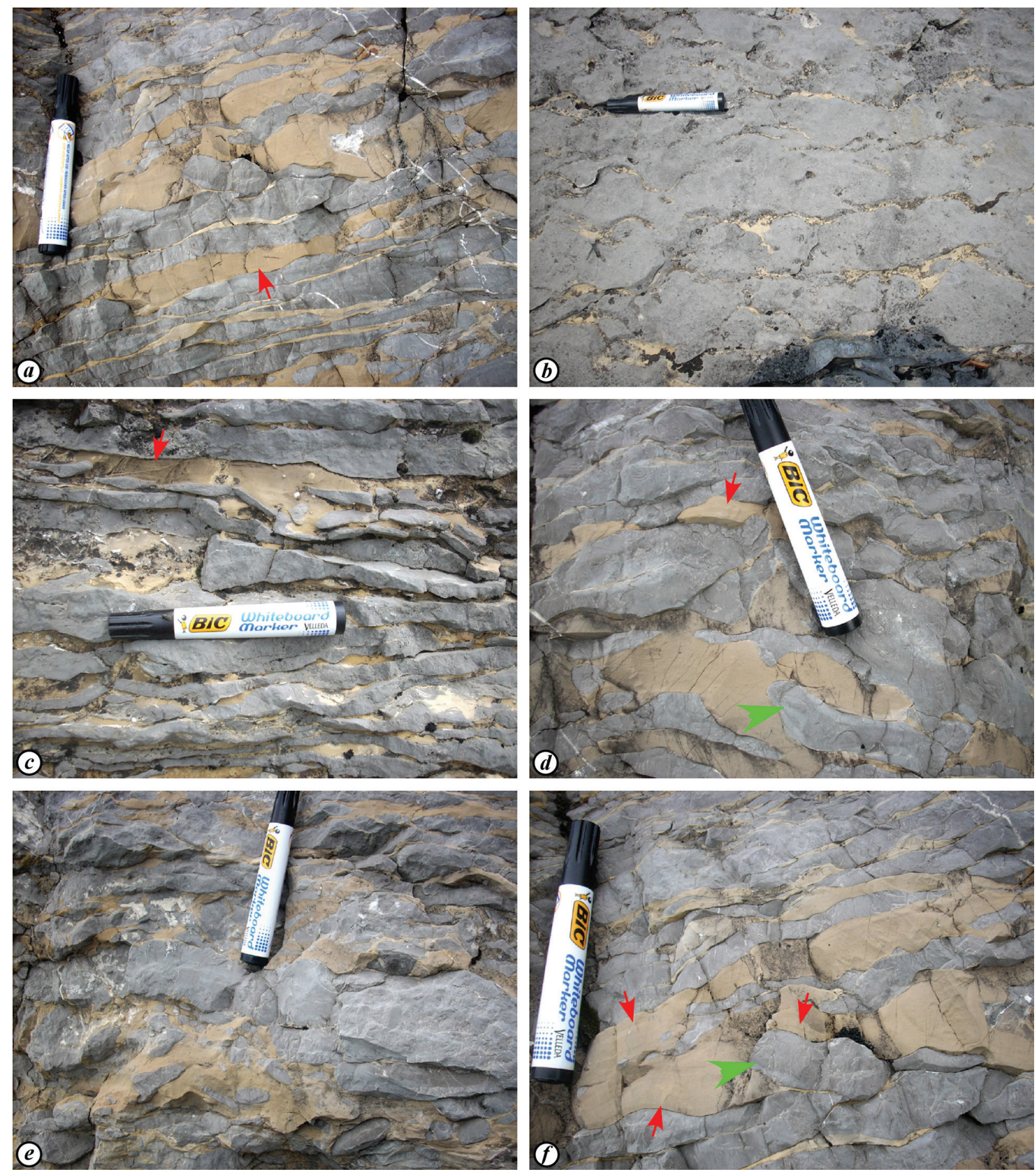

Fig. 5. Selectively dolomitized layers in ribbon rocks of the Zgorigrad Member: $a$ ) heterolithic alternation of ochre-coloured dolostones and grey-coloured limestones. Note the variable thicknesses and sharp boundaries of vertically adjacent layers; $b$ ) dolostone lenses in limestone resembling the flaser bedding in siliciclastic deposits; $c$ ) cracked, disrupted, and brecciated limestone layers with dolomitic material filling the cracks and space between clasts; $d$ ) large pebble clast of limestone (green arrow) embedded in dolostone layer; $e$ ) numerous limestone clasts with various sizes, shapes, degree of roundness and orientation, "floating" in dolostone matrix; $f$ ) enlarged view of ( $a$ ) showing flat limestone clast (green arrow) embedded in dolostone. Note: Red arrows indicate vague horizontal lamination, which is locally affected by soft deformation and bends around larger limestone clasts. 
intercrystalline clay or calcite micrite in contrast to the surrounding rock matrix. Dissolution seams and low-amplitude stylolites are locally developed and occur preferentially in the dolostone layers with some dolomite crystals crosscutting these pressure solution features (Fig. 6i).

\section{ANALYTICAL RESULTS}

Data from the XRD analysis show great variations in the dolomite stoichiometry and degree of ordering with some overlapping between samples from the burrows and the ribbon rocks (Table 1 ). The burrow-related dolomite is non-stoichiometric (52.3-54.7 mole\% $\mathrm{CaCO}_{3}$, average 53.33 mole $\% \mathrm{CaCO}_{3}, \mathrm{n}=7$ ), and the degree of ordering ranges from 0.52 to 0.78 (average $0.65, n=7$ ). The dolomite of the ribbon rocks is more Ca-rich (53.9-56.0 mole\% $\mathrm{CaCO}_{3}$, average 55.1 mole $\% \mathrm{CaCO}_{3}, \mathrm{n}=7$ ), and the degree of ordering is in a more narrow range, from 0.55 to 0.65 (average $0.60, n=7)$. Small amounts of calcite are recorded in most samples, while quartz, illite, and minor chlorite are detected only in samples from dolostone layers of the ribbon rocks.

The insoluble residue of dolomitic layers in the ribbon rocks shows values from $6.60 \%$ to $20.57 \%$ (average $10.78 \%, \mathrm{n}=7$ ), and the $\mathrm{Al}_{2} \mathrm{O}_{3}$ content is between $0.38 \%$ and $2.17 \%$ (average $1.09 \%, \mathrm{n}=7$ ). The insoluble residue of limestone layers in the ribbon rocks ranges from $1.80 \%$ to $3.22 \%$ (average $2.69 \%, n=5$ ), and the $\mathrm{Al}_{2} \mathrm{O}_{3}$ content is between $0.04 \%$ and $0.11 \%$ (average $0.07 \%, \mathrm{n}=5$ ).

The $\delta^{13} \mathrm{C}$ and $\delta^{18} \mathrm{O}$ values of the burrow-related dolomite range from $-0.69 \%$ to $-1.15 \%$ (average $-0.88 \%$, $n=3$ ) and from $-4.42 \%$ o to $-5.58 \%$ o (average $-4.95 \%$, $n=3$ ), respectively. The dolomite in the ribbon rocks has $\delta^{13} \mathrm{C}$ values between $1.24 \%$ and $1.67 \%$ (average $1.48 \%$ o, $\mathrm{n}=3$ ), and $\delta^{18} \mathrm{O}$ values between $-6.73 \%$ and -8.02\%o (average $-7.47 \%$, $n=3$ ).

\section{INTERPRETATION AND DISCUSSION}

\section{Dolomitized burrows}

The Anisian limestones with dolomitized burrows have been interpreted as shallow subtidal deposits in oxygenated, normal marine seawater of the inner ramp (Mogilata Formation) and mid-ramp (Babina Formation) zones (Chatalov and Vangelov, 2001; Chatalov, 2013a, 2018). The abundant micritic matrix in these rocks indicates deposition in poorly agitated settings, where predominantly deposit-feeding and suspensionfeeding organisms burrowed into the muddy softground, firmground, or hardground substrate. On the basis of their overall characteristics, the trace fossils can be assigned to the Cruziana ichnofacies with local overprinting by the substrate-controlled Glossifungites and Trypanites ichnofacies (see MacEachern et al., 2007; Seilacher, 2007; Buatois and Mángano, 2011; Knaust et al., 2012).

Table 1

Analytical data for the studied dolomites

\begin{tabular}{|c|c|c|c|c|c|c|}
\hline Sample* & $\begin{array}{c}\text { mole \% } \\
\mathrm{CaCO}_{3}\end{array}$ & $\frac{\mathrm{I}(015)}{\mathrm{I}(110)}$ & $\begin{array}{c}\text { insoluble } \\
\text { residue (wt. \%) }\end{array}$ & $\begin{array}{c}\mathrm{Al}_{2} \mathrm{O}_{3} \\
\text { (wt. \%) }\end{array}$ & $\begin{array}{c}\delta^{13} \mathrm{C} \\
(\% \circ \mathrm{V}-\mathrm{PDB})\end{array}$ & $\begin{array}{c}\delta^{18} \mathrm{O} \\
(\% \circ \mathrm{V}-\mathrm{PDB})\end{array}$ \\
\hline $1-\mathrm{Bu}$ & 54.0 & 0.58 & & & & \\
\hline 2-Bu & 53.0 & 0.52 & & & -0.69 & -5.58 \\
\hline 3-Bu & 52.3 & 0.71 & & & -0.81 & -4.42 \\
\hline 4-Bu & 54.7 & 0.57 & & & & \\
\hline 5-Bu & 52.3 & 0.78 & & & & \\
\hline 6-Bu & 53.2 & 0.64 & & & -1.15 & -4.84 \\
\hline 7-Bu & 53.8 & 0.73 & & & & \\
\hline 1-Rb-d & 55.0 & 0.65 & 7.80 & 0.38 & & \\
\hline 2-Rb-d & 54.7 & 0.63 & 6.60 & 0.42 & 1.24 & -7.66 \\
\hline 3-Rb-d & 54.7 & 0.55 & 9.96 & 1.59 & & \\
\hline 4-Rb-d & 55.7 & 0.57 & 8.91 & 0.59 & 1.53 & -6.73 \\
\hline 5-Rb-d & 55.4 & 0.61 & 14.16 & 1.74 & & \\
\hline 6-Rb-d & 56.0 & 0.59 & 20.57 & 2.17 & & \\
\hline 7-Rb-d & 53.9 & 0.62 & 7.45 & 0.77 & 1.67 & -8.02 \\
\hline 8-Rb-l & & & 2.65 & 0.08 & & \\
\hline 9-Rb-l & & & 1.80 & 0.04 & & \\
\hline 10-Rb-l & & & 3.22 & 0.11 & & \\
\hline 11-Rb-l & & & 2.79 & 0.06 & & \\
\hline 12-Rb-l & & & 2.99 & 0.08 & & \\
\hline
\end{tabular}

* Letters in the sample names indicate: $\mathrm{Bu}$ - dolomitized burrows, $\mathrm{Rb}$ - ribbon rocks, $\mathrm{d}$ - dolomitic layers, $\mathrm{l}$ - limestone layers. 

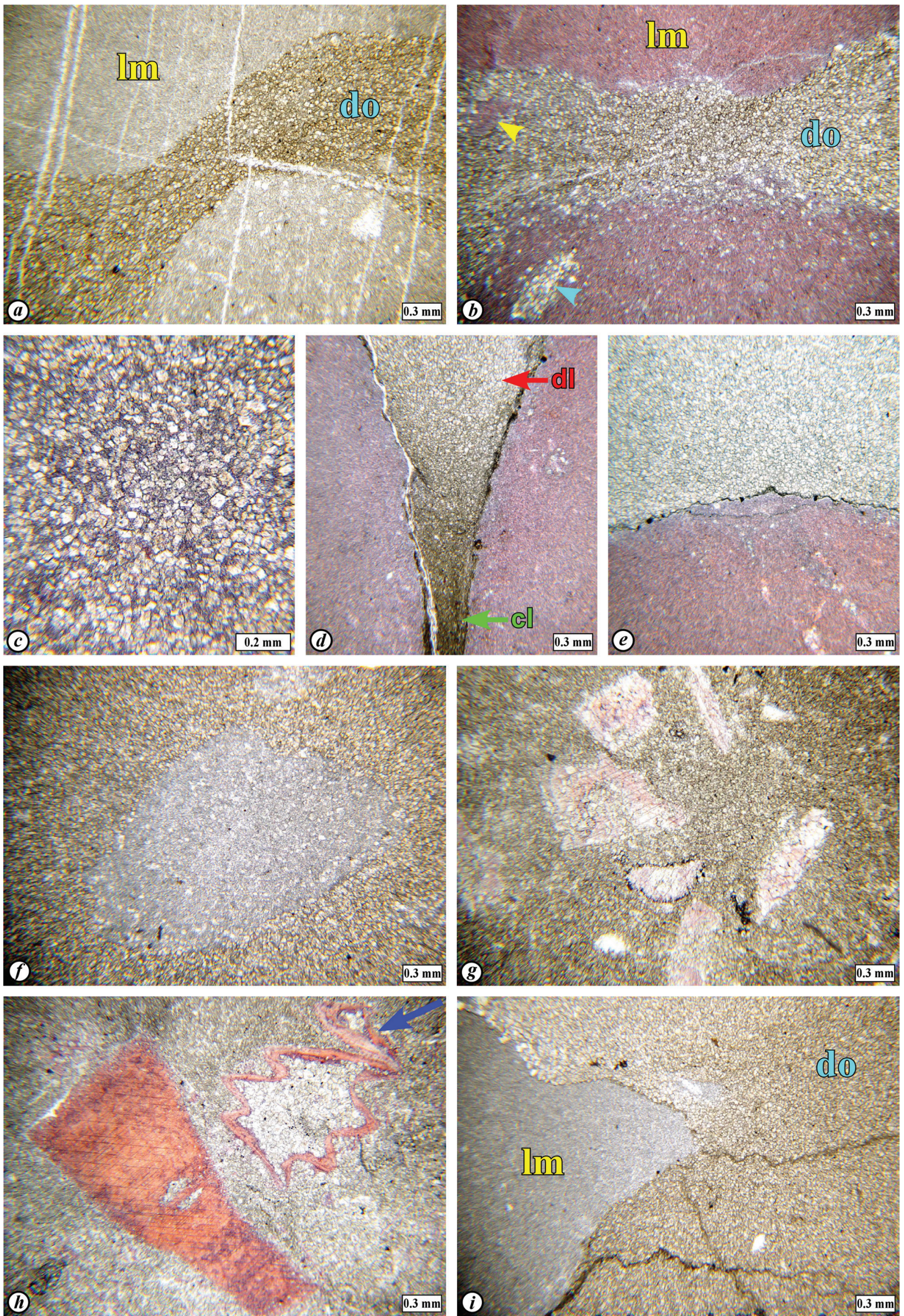
Fig. 6. Microphotographs of dolomite in the ribbon rocks: $a$ ) sharp contact between clay-poor limestone layer (lm) and clay-rich dolostone layer (do); $b$ ) dolomite crystals dispersed in limestone ( $\mathrm{lm}$ ) close to the boundary with dolostone (do). Also note nondolomitized clast (yellow arrow) in the dolostone and dolomitized clast (blue arrow) in the limestone; $c$ ) euhedral dolomite replacing clay-rich calcitic micrite; $d$ ) vertical crack in limestone layer showing gradual increase in the amount of dolomite (dl) upward from a clay-rich (cl) domain; $e$ ) ferroan dolomite in dolostone layer (upper part of the microphotograph); $f$ ) slightly dolomitized limestone clast in dolostone layer; $g$ ) non-dolomitized and poorly dolomitized skeletal debris in dolostone matrix; $h$ ) non-dolomitized crinoid (left) and brachiopod (arrow) bioclasts in dolostone layer. The articulated brachiopod shell is crushed as a result of mechanical compaction and filled with dolomite cement; i) low-amplitude stylolites developed in dolostone (do) and terminating at the contact with adjacent limestone $(\mathrm{lm})$. Note that some dolomite crystals crosscut these pressure solution features. All thinsections, except $a, f$ and $i$ are stained, and all microphotographs are in plane-polarized light.

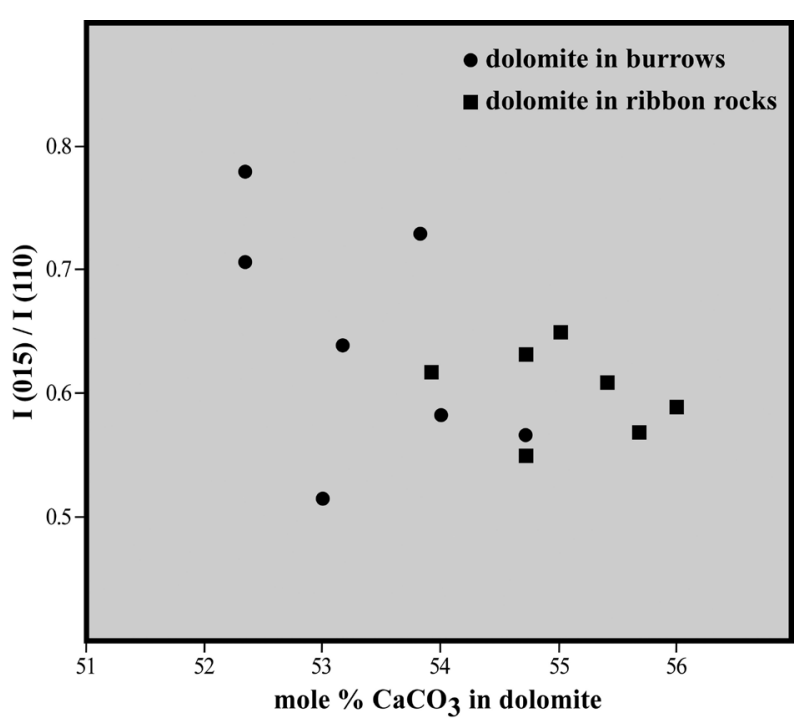

Fig. 7. Cross-plot of stoichiometry vs. degree of ordering of the studied dolomites.

Dolomitization of the burrows occurred during the early diagenesis with a local source of $\mathrm{Mg}$, which is evidenced by the fabric-selective character of replacement, sharp contacts with the host rock (with local truncation of allochems), incorporation of nondolomitized clasts and bioclasts from the adjacent limestone, and crosscutting relationship with dissolution seams and stylolites. Moreover, the crypto- to microcrystalline dolomite with predominantly planar crystal faces suggests low-temperature $\left(<50{ }^{\circ} \mathrm{C}\right)$ dolomite formation (Gregg and Sibley, 1984), i.e., in a near-surface setting (sensu Machel, 1999). The variable Ca excess and degree of ordering (Fig. 7) further indicate early diagenetic origin from non-evaporitic, dolomitizing solutions with lower $\mathrm{Mg} / \mathrm{Ca}$ ratio (Lumsden and Chimahusky, 1980; Sperber et al., 1984; Kaczmarek and Sibley, 2011). The Middle Triassic dolomitized burrows are similar to other studied ex- amples from the geological record in terms of petrographic features (Morrow, 1978; Rao, 1990; Gingras et al., 2004; Rameil, 2008; Corlett and Jones, 2012; Baniak et al., 2014; Baldermann et al., 2015), as well as dolomite stoichiometry and degree of cation ordering (Morrow, 1978; Rao, 1990; Baldermann et al., 2015). On a broader scale, the small crystal size and Ca-rich composition of the burrow-related dolomite characterize the so-called organogenic (Compton, 1988), or microbially mediated (Petrash et al., 2017), low-temperature dolomites from modern and ancient peritidal, shallow-marine and deep-sea environments (Mazzullo, 2000).

Burrowing substantially alters the physical and chemical character of sediment substrates and may control the formation of low-temperature dolomite and the selective dolomitization of burrows (Gingras et al., 2004). Modification and redistribution of the grain size is caused by movement and digestion activities of burrowing organisms (Bromley, 1996). Reduction of the substrate grain size creates larger surface area of the sediment particles and greater number of nucleation sites that may favour dolomitization (Chow and Longstaffe, 1995; Zenger 1996). Conversely, increase of the grain size would lead to higher porosity and permeability, and hence provide a conduit for the circulation of dolomitizing fluids. Biochemical modification of burrowed substrates is related to the incorporation of concentrated organic matter in the form of mucous and/or faecal material (Petrash et al., 2011, and references therein) providing a microenvironment for bacterial colonization (Gingras et al., 2004). According to the model proposed by Gingras et al. (2004), the microbial oxidation of organic matter close to the sediment-water interface, i.e., in the oxic zone, produces $\mathrm{CO}_{2}$, which may enhance carbonate dissolution during the early diagenesis. The presence of free sulphate ions further inhibits kinetically the dolomite formation and lowers the $\mathrm{Mg} / \mathrm{Ca}$ ratio by bonding with $\mathrm{Mg}^{2+}$ ions. In the anoxic zone, however, the reaction between $\mathrm{NH}_{3}$ (released from the breakdown of proteins in organic 
matter) and $\mathrm{H}_{2} \mathrm{O}$ raises the $\mathrm{pH}$ of ambient seawater, which, in turn, increases the activity of the carbonate ion. Under such reducing conditions, $\mathrm{SO}_{4}{ }^{2-}$ ions are consumed by sulphate-reducing bacteria, leaving a high $\mathrm{Mg} / \mathrm{Ca}$ ratio. Metal enrichments in the organic burrow lining and interstitial (marine) water provide a source of $\mathrm{Mg}$ for dolomitization (Mirsal and Zankl, 1985). By raising the $\mathrm{pH}$ in interstitial pore water, sulphate-reducing bacteria decrease the solubility of metals, resulting in increased metal concentrations in the burrows (Corlett and Jones, 2012). Thus, the combination of reducing conditions, elevated $\mathrm{pH}$, and low sulphate levels favours the precipitation of dolomite in burrows during the early diagenesis.

In the case studied, the presence of disseminated fine-grained pyrite in the burrow fills implies that bacterial sulphate reduction was an important control on the dolomite formation (e.g., Berner et al., 1985). Another clue is the non-ferroan composition of the dolomite, considering that sulphate-reduction dolomites are generally Fe-poor because available iron is rapidly incorporated into sulphide minerals and/or bound to organic substrate (Mazzullo, 2000; Macquaker et al., 2014; Petrash et al., 2017). Furthermore, the carbon isotope values $\left(\delta^{13} \mathrm{C}\right)$ of the burrow-related dolomite (Fig. 8) are typical for peritidal and shallow subtidal dolomites precipitated during sulphate reduction (Mazzullo, 2000). The recorded $\delta^{13} \mathrm{C}$ signatures are slightly depleted in comparison to the carbon isotope values of Middle Triassic seawater based on brachio-

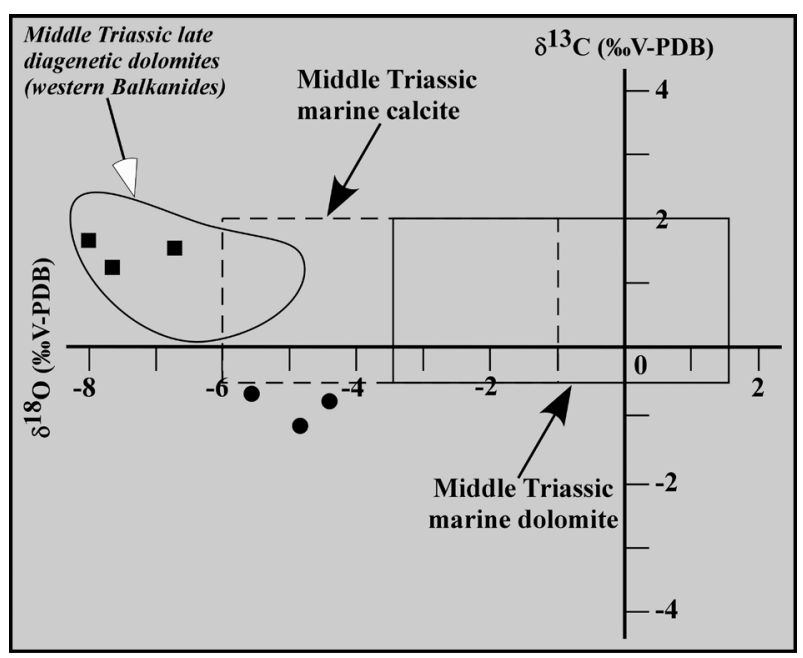

Fig. 8. Cross-plot of $\delta^{18} \mathrm{O}$ vs. $\delta^{13} \mathrm{C}$ of the analysed dolomites. The isotope values for Middle Triassic marine calcite are from Korte et al. (2005). The estimated $\delta^{18} \mathrm{O}$ values for Middle Triassic marine dolomite are based on equilibrium ${ }^{18} \mathrm{O}$ enrichment of $2.6 \%$ in low-temperature dolomite relative to calcite $\Delta^{18}$ Odolcal (Vasconcelos et al., 2005). The outlined field for Middle Triassic late diagenetic dolomites of the western Balkanides is from Chatalov (2014). Note: The used symbols are the same as in Figure 7. pods (Veizer et al., 1999; Korte et al., 2005). These data indicate that the carbon for dolomite formation in the burrows was largely derived from seawater and/ or dissolution of precursor carbonate sediments, and partly derived from the decomposition of organic matter (cf. Gingras et al., 2004; Corlett and Jones, 2012). The slightly depleted $\delta^{13} \mathrm{C}$ compositions may reflect dolomite precipitation, either during early sulfate reduction (i.e., prior to maximum ${ }^{12} \mathrm{C}$ enrichment in pore fluids) or in sediments with relatively small amount of organic matter (Compton 1988; Mazzullo, 2000).

The interpretation of $\delta^{18} \mathrm{O}$ from dolostones is controversial because $\delta^{18} \mathrm{O}$ values of dolomite are influenced by many variables, including the isotopic composition of dolomitizing fluids, temperature, kinetics, and dolomite stoichiometry (see Swart, 2015; Ren and Jones, 2017, and references therein). The recorded oxygen isotope signatures of the burrow-related dolomite are depleted in comparison to the estimated values of Middle Triassic marine dolomite, if an equilibrium ${ }^{18} \mathrm{O}$ enrichment of $2.6 \%$ in low-temperature dolomite relative to calcite $\Delta^{18}$ Odol-cal $\left(\delta^{18}\right.$ Odolomite $-\delta^{18}$ Ocalcite V-PDB) is assumed (Vasconcelos et al. 2005). This difference suggests that the original oxygen isotope values were reset with increasing burial and temperature as a result of recrystallization (e.g., Mazzullo, 1992; Kupecz et al., 1993; Machel, 1997). Such conclusion is consistent with the statement of Machel (2004) that most dolomites formed in nearsurface settings tend to recrystallize during burial due to their thermodynamic instability in conditions of increasing temperature and pressure and changing fluid composition. In this case, possible petrographic evidence for recrystallization includes the heterogeneous crystal size of the dolomite in some burrows (i.e., mixed crypto- to microcrystalline texture, coarser euhedral crystals in more fine-grained matrix) and the presence of non-planar crystal boundaries (see Rott and Qing, 2013).

The fine-crystalline dolomite forming irregular strips along the periphery of some burrows is interpreted as a result of late diagenetic formation and was probably derived from dissolution of crypto- to microcrystalline dolomite of the burrow fills (see Gingras et al., 2004).

\section{Limestone-dolostone ribbon rocks}

Some macroscopic characteristics of the dolostone layers, e.g., small thickness, stratiform pattern and preserved laminations, along with the fine crystal size, planar crystal faces, non-stoichiometry (with Ca-excess) and moderate degree of ordering of the dolomite (Fig. 7), may indicate that low-temperature dolomitization occurred syndepositionally or in the early diagenesis, i.e., in a near-surface setting. Thus, a possible origin of the dolomite can be related to penecontemporaneous, microbially mediated dolomitization in shallow-marine to supratidal and hemi- 
pelagic to pelagic environments (sensu Machel, 2004), or dolomite formation in hypersaline settings (e.g., sabkha). Ancient ribbon carbonates have been reported from a wide spectrum of depositional environments, e.g., from peritidal to deep subtidal (see Chatalov, 2017a, 2018, and references therein). Field and micropetrographic evidence have recently been presented that the carbonate rocks of the Zgorigrad Member from the Vratsa region were deposited in a mid-outer ramp setting developed on a distally steepened part of the ramp profile (Chatalov, 2018). Therefore, penecontemporaneous organogenic or hypersaline dolomitization in such slope environment is an unlikely scenario.

Several petrographic features of the dolostone layers in the ribbon rocks imply strong lithologic control on the dolomitization process. The sharp contacts with the limestone layers, the incorporation of non-dolomitized or slightly dolomitized limestone clasts, the presence of unreplaced calcitic bioclasts in the dolomitic matrix, and the rare appearance of selectively dolomitized clasts in the limestone layers close to the contact with the dolostone layers all indicate that the dolostones had a different mineralogy compared to the limestones prior to the dolomitization event. Furthermore, the presence of calcite micrite and clay-sized siliciclastic material between the dolomite crystals and the gradation from non-dolomitized clay-rich domains to strongly dolomitized domains in crack fills of the limestone layers suggest that the dolostones consisted primarily of variable amounts of $\mathrm{CaCO}_{3}$ and clay minerals. This conclusion is supported by the preferential development of dissolution seams and low-amplitude stylolites in the dolostone layers, which points to higher clay content relative to the limestone layers (Bathurst, 1987; Aharonov and Katsman, 2009). In addition, the insoluble residue and $\mathrm{Al}$ content in the dolostones show significantly higher values (with proportional increase) in comparison with the limestones (Fig. 9), and the XRD analyses of bulk dolostone samples reveal the common presence of illite and minor chlorite (cf. Török, 2000). The originally different mineralogical composition of the limestone and dolostone layers is also indicated by unequivocal evidence for their differential diagenesis under shallow burial conditions (i.e., Westphal et al. 2000). Thus, the ductile behaviour of the dolostone layers (deformed lamination, crack fills in the limestone layers, randomly "floating" limestone clasts) and the brittle deformation of the limestone layers (cracking, disruption, brecciation) can be explained by earlier lithification of the latter while the primarily argillaceous carbonate layers were still unconsolidated (see McHargue and Price, 1982; Coniglio and James, 1988; Demicco and Hardie, 1994). In situ fragmentation of early lithified limestone layers and subsequent deformation of ribbon sediments may result from: a) seismic shocks and resultant gravity-induced movements (Kullberg et al., 2001); b) compaction, fluidization, and expulsion of

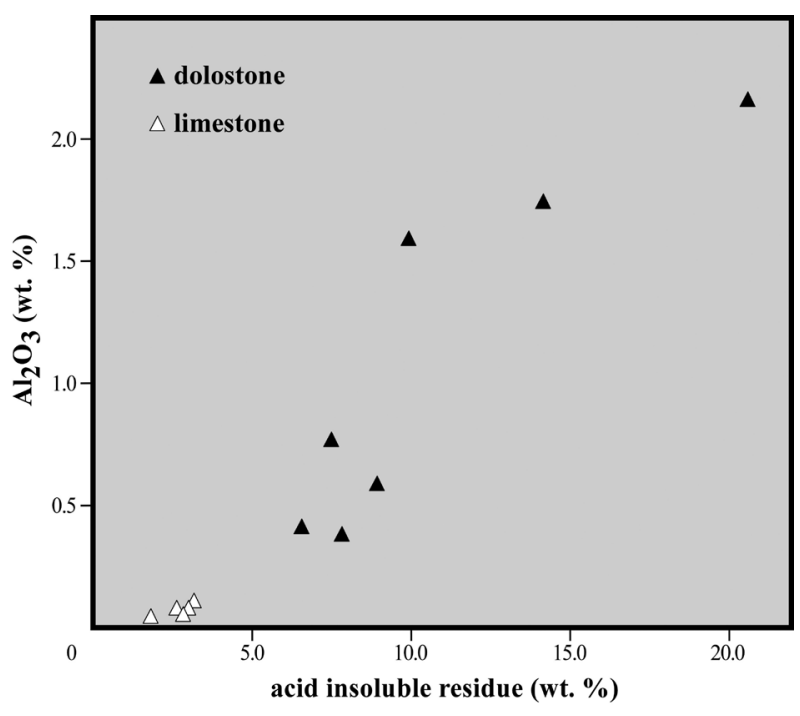

Fig. 9. Cross-plot of acid insoluble residue vs. Al content in dolostone layers and limestone layers of the ribbon rocks.

pore water during shallow burial (Kwon et al., 2002); or c) combined influence of an external triggering force and burial compaction (Chen et al., 2009). In this study case, the presence of slumps in the vertical interval with ribbon rocks and some other evidence for gravity-driven transport in the Zgorigrad Member (Chatalov, 2018) suggest that an oversteepened slope must have particularly favoured the early ductile and brittle deformation (cf. Sherman et al., 2001) of the argillaceous and pure carbonate layers, respectively, while further deformation took place in shallow burial conditions.

The selective dolomitization of originally clayrich carbonate layers by non-stoichiometric dolomite, together with the presence of unreplaced allochems and variable amounts of argillaceous calcitic matrix, implies a local and limited source of $\mathrm{Mg}$ for the dolomite formation. It has widely been demonstrated that argillaceous carbonate rocks are commonly dolomitized (Kahle, 1965; McHargue and Price, 1982; Gregg, 1988; Demicco and Hardie, 1994; Ali, 1995; Glumac and Walker, 2002; Carnell and Wilson, 2004; Li et al., 2016). In a seminal paper, McHargue and Price (1982) proposed a hypothesis that diagenetic transformation of smectite to illite during burial may supply $\mathrm{Mg}$ ions for late-stage dolomitization. The illitization of smectite takes place over a broad temperature range from $50-60^{\circ} \mathrm{C}$ to $140-180^{\circ} \mathrm{C}$ (Pollastro, 1993; Milliken, 2003) and is accompanied by the release of metal ions to the pore fluid (Boles and Franks, 1979; Awwiller, 1993). It has particularly been suggested that $\mathrm{Fe}$ and $\mathrm{Mg}$ are released at temperatures $>100{ }^{\circ} \mathrm{C}$, presumably up to about $125{ }^{\circ} \mathrm{C}$ (Boles and Franks, 1979). Clay min- 
eral transformations have been interpreted as a major control on dolomitization in argillaceous carbonates (McHargue and Price, 1982; Gregg, 1988; Ali, 1995; Glumac and Walker, 2002) and limestones adjacent to shales (Mattes and Mountjoy, 1980; Gawthorpe, 1987; Srinivasan et al., 1994; Suchý et al., 1996; Sabbagh Bajestani et al., 2018), but also in sandstones (Śliwiński et al., 2016) and volcaniclastic rocks (Zhu et al., 2017). In this case, several lines of evidence support the assumption that illitization of smectite during burial supplied Mg ions for dolomitization of the ribbon rocks, e.g., the selective replacement of argillaceous carbonate layers and the presence of illite (vs. absence of smectite) in the dolostones. Furthermore, the local formation of ferroan dolomite was most probably related to release of Fe ions during the illitization process, and thus reflects reducing (i.e., burial) conditions during the dolomitization (Taylor and Sibley, 1986; Gregg, 1988; Glumac and Walker, 2002). The presence of anhedral dolomite crystals suggests formation above the critical roughening temperature (CRT), which is estimated to be between $50{ }^{\circ} \mathrm{C}$ and $100{ }^{\circ} \mathrm{C}$, while the formation of euhedral to subhedral dolomite above the CRT may have been controlled by impurities (i.e., clays) that stabilized crystal faces (Gregg and Sibley, 1984; Sibley and Gregg, 1987). The crushed brachiopod and bivalve shells (filled with dolomite cement) and the crosscutting stylolites and dissolution seams (truncated by some dolomite crystals) indicate that the dolomitization post-dated the mechanical compaction and occurred prior to and during the chemical compaction of the primarily argillaceous carbonate layers. Therefore, the relative timing of the dolomitization process can be interpreted as related to intermediate burial depths, i.e., from 600-1000 m to 2000-3000 m (sensu Machel, 1999), which is consistent with the presumption that clay mineral transformations supplied $\mathrm{Mg}$ ions for the dolomite formation. The recorded oxygen isotope values $\left(\delta^{18} \mathrm{O}\right)$ of the dolomite are considerably lower than the predicted values for dolomite derived from Middle Triassic seawater (Fig. 8) and may attest to high-temperature dolomite formation (sensu Allan and Wiggins, 1993), i.e., corresponding to the temperature range of smectite illitization. It is noteworthy that similar oxygen isotope values were reported from dolomitic layers of Cambrian and Ediacaran ribbon rocks by Glumac and Walker (2002) and Li et al. (2016), respectively.

Recently, Li et al. (2016) questioned the well-established hypothesis of McHargue and Price (1982) by studying the Mg isotope compositions of dolomite in Ediacaran ribbon rocks from South China. A numerical model calculation indicated that clay mineral transformation cannot provide sufficient Mg for dolomitization of the argillaceous layers, and instead Li et al. (2016) speculated that contemporaneous seawater might be the primary Mg source. These authors proposed a kinetic model, in which early differential diagenesis of the clay-rich and clay-poor layers promotes $\mathrm{Ca}-\mathrm{Mg}$ exchange between them, and as a result elevated pore-water $\mathrm{Mg} / \mathrm{Ca}$ ratio in the clay-rich layers favours dolomite formation. Similarly, in an earlier study of Cambrian ribbon rocks, Glumac and Walker (2002) suggested that dolomitizing fluids may at first be provided by diffusion of overlying seawater and dissolution of some of the host carbonate sediments, and subsequently by compaction and expulsion of pore water from the argillaceous carbonate layers, with trapped seawater and ions adsorbed on clay-mineral surfaces serving as the Mg source. According to Glumac and Walker (2002), additional Mg ions for the dolomite formation may be supplied by release of structural water from clay minerals during the late diagenetic illitization of smectite. In the case studied, the possible role of seawater in the dolomitization process is implied by the measured $\delta^{13} \mathrm{C}$ values of the dolomite, which point to seawater-derived pore fluids. If so, the dolomitization of the argillaceous carbonate layers may have been a continuous process related to changing diagenetic conditions and different sources of Mg during shallow and deep burial. In conclusion, it may be inferred that the observed variations of the dolomite amount in the Anisian ribbon rocks reflect: a) variations in the distribution, amount and composition of clay minerals in the primary sediments (McHargue and Price, 1982); and/or b) the efficiency of Mg supply through ion exchange between lithologically different layers plus rapid termination of dolomitization during the early differential diagenesis (Li et al., 2016). Also, the preservation of calcian dolomite must be attributed to a semi-closed diagenetic system with low water/rock ratio (Lumsden and Chimahusky, 1980; Sperber et al., 1984), in which the impermeable limestones prevented the supply of allochthonous Mg ions during deep burial.

\section{CONCLUSIONS}

Two different types of fabric-selective dolomitization are recognized macroscopically in Anisian carbonate deposits from Northwest Bulgaria. The dolomitization of burrows in limestones occurred during the early diagenesis with a local source of $\mathrm{Mg}$ from non-evaporitic solutions with low Mg/Ca ratio. The low-temperature precipitation of non-stoichiometric (with Ca excess) dolomite was microbially mediated and controlled by bacterial sulphate reduction. The carbon for dolomite formation was largely derived from seawater and/or dissolution of precursor calcareous sediments, and partly derived from the decomposition of organic matter. The selective dolomitization of primarily argillaceous carbonate layers in limestone-dolostone ribbon rocks was mainly associated with an autochthonous source of Mg. Conversion of smectite to illite at intermediate burial depths supplied Mg (and locally $\mathrm{Fe}$ ) ions for the formation of Ca-rich dolomite. However, 
differential diagenesis of the clay-rich and clay-poor layers may also have favoured early dolomite precipitation, whereupon contemporaneous seawater was the primary Mg source during shallow burial. This study demonstrates that various factors control the formation of fine-grained, non-stoichiometric dolomite with fabric-selective character of replacement recognizable in the field.

\section{Acknowledgements}

The analytical work of P. Boteva, T. Stoilkova-Ilieva, V. Georgieva and V. Nakova (Faculty of Geology and Geography, Sofia University “St Kliment Ohridski”) is greatly acknowledged. S. Arkadaksky (Isobrine Solutions Inc., Edmonton, Canada) is gratefully thanked for performing the isotope analyses.

\section{REFERENCES}

Aharonov, E., Katsman, R. 2009. Interaction between pressure solution and clays in stylolite development: insights from modeling. American Journal of Science 309, 607-632.

Ajdanlijsky, G., Götz, A.E., Strasser, A. 2018. The Early to Middle Triassic continental-marine transition of NW Bulgaria: sedimentology, palynology and sequence stratigraphy. Geologica Carpathica 69, 129-148.

Ali, M. 1995. Carbonate cement stratigraphy and timing of diagenesis in a Miocene mixed carbonate-clastic sequence, offshore Sabah, Malaysia: constraints from cathodoluminescence, geochemistry and isotope studies. Sedimentary Geology 99, 191-214.

Allan, J.R., Wiggins, W.D. 1993. Dolomite Reservoirs: Geochemical Techniques for Evaluating Origin and Distribution. American Association of Petroleum Geologists, Continuing Education Course Note Series 36, 129 pp.

Angelov, V., Dimitrova, R., Haydutov, I., Tronkov, D., Sapunov, I., Tchoumatchenco, P., Tzankov, Tz., Yanev, S., Popov, N., Nikolov, T. 1992. Geological map of Bulgaria. Scale 1:100 000. Berkovitsa map sheet. Geology and Mineral Resources Committee, Enterprise of Geophysical Survey and Geological Mapping.

Armenteros, I. 2010. Diagenesis of carbonates in continental settings. In: Alonso-Zarza, A.M., Tanner, L.H. (Eds), Carbonates in continental settings: Geochemistry, diagenesis and applications. Developments in sedimentology 62, 62-151.

Asseretto, R., Tronkov, D., Chatalov, G. 1983. Mogila Formation (Lower-Middle Triassic) - a new formation in West Bulgaria. Geologica Balcanica 13, 25-27 (in Russian, with English abstract).

Awwiller, D.N. 1993. Illite/smectite formation and potassium mass transfer during burial diagenesis of mudrocks: a study from the Texas Gulf Coast Paleocene-Eocene. Journal of Sedimentary Petrology 63, 501-512.

Baldermann, A., Deditius, A.P., Dietzel, M., Fichtner, V., Fischer, C., Hippler, D., Leis, A., Baldermann, C., Mavromatis, V., Stickler, C.P., Strauss, H. 2015. The role of bacterial sulfate reduction during dolomite precipitation: implications from Upper Jurassic platform carbonates. Chemical Geology 412, 1-14.

Baniak, G.M., Amskold, L., Konhauser, K.O., Muehlenbachs, K., Pemberton, S.G., Gingras, M.K. 2014. Sabkha and burrowmediated dolomitization in the Mississippian Debolt Formation, Northwestern Alberta, Canada. Ichnos 21, 158-174.

Barale, L., Bertok, C., Talabani, N.S., d’Atri, A., Martire, L., Piana, F., Préat, A. 2016. Very hot, very shallow hydrothermal dolomitization: an example from the Maritime Alps (north-west Italy-south-east France). Sedimentology 63, 2037-2065.
Bathurst, R.G.C. 1987. Diagenetically enhanced bedding in argillaceous platform limestones: stratified cementation and selective compaction. Sedimentology 34, 749-778.

Bayet-Goll, A., Chen, J., Moussavi-Harami, R., Mahboubi, A. 2015. Depositional processes of ribbon carbonates in Middle Cambrian of Iran (Deh-Sufiyan Formation, Central Alborz). Facies 61, 1-18.

Berner, R.A., De Leeuw, J.W., Spiro, B., Murchison, D.G., Eglinton, G. 1985. Sulphate reduction, organic matter decomposition and pyrite formation. Philosophical Transactions of the Royal Society of London A: Mathematical, Physical and Engineering Sciences 315, 25-38.

Bertok, C., Martire, L., Perotti, E., D’Atri, A., Piana, F. 2011. Middle-Late Jurassic syndepositional tectonics recorded in the Ligurian Briançonnais succession (Marguareis-Mongioie area, Ligurian Alps, NW Italy). Swiss Journal of Geosciences 104, 237-255.

Boles, J.R., Franks, S.G. 1979. Clay diagenesis in Wilcox Sandstones of southwest Texas: implications of smectite diagenesis on sandstone cementation. Journal of Sedimentary Petrology 49, 59-70.

Bromley, R.G. 1996. Trace fossils: biology, taphonomy and applications ( $2^{\text {nd }}$ ed.). Chapman \& Hall, London, $361 \mathrm{pp.}$

Buatois, L.A., Mángano, M.G. 2011. Ichnology: organismsubstrate interactions in space and time. Cambridge University Press, New York, 358 pp.

Bullen, S.R., Sibley, D.F. 1984. Dolomite selectivity and mimic replacement. Geology 12, 655-658.

Carnell, A., Wilson, M.E.J. 2004. Dolomites in southeast Asia: varied origins and implications for hydrocarbon exploration. In: Braithwaite, C.J.R., Rizzi, G., Darke, G. (Eds), The geometry and petrogenesis of dolomite hydrocarbon reservoirs. Geological Society, London, Special Publications 235, 255-300.

Čatalov, G. 1988. Ladinian-Karnian terrigenous invasion and the bifurcation of the Triassic carbonate platform in Bulgaria. Comptes rendus de l'Académie bulgare des Sciences 41, 99-102.

Chatalov, A. 1994. Cryptalgal laminated dolomicrites and related flat-pebble conglomerates in the Mogila Formation (Lower-Middle Triassic). Annuaire de l'Université de Sofia "St Kliment Ohridski", Faculté de Géologie et Géographie 86 (1), 77-94.

Chatalov, A. 1997. Sedimentology of the carbonate rocks of the Mogilata Formation (Spathian-Anisian) in the western Balkanides. PhD thesis, Sofia University "St Kliment Ohridski”, 233 pp. (in Bulgarian).

Chatalov, A. 1999a. Calcitization of dolomite in the Spathian and Anisian carbonate rocks from the Western Balkanides, 
Bulgaria. Neues Jahrbuch für Geologie und Paläontologie, Monatshefte 1999, 614-640.

Chatalov, A. 1999b. Mimetic dolomitization of allochems from the Svidol Formation (Spathian) in the Iskar river valley, northwestern Bulgaria. Comptes rendus de l'Académie bulgare des Sciences 52, 63-66.

Chatalov, A. 2009. Primary and secondary fenestral porosity in Middle Triassic subtidal grainstones from the Belogradchik strip, NW Bulgaria: implications for unconformity-related diagenesis. Comptes rendus de l'Académie bulgare des Sciences 62, 85-96.

Chatalov, A. 2013a. A Triassic homoclinal ramp from the Western Tethyan realm, Western Balkanides, Bulgaria: integrated insight with special emphasis on the Anisian outer to inner ramp facies transition. Palaeogeography, Palaeoclimatology, Palaeoecology 386, 34-58.

Chatalov, A. 2013b. Flow chart for micropetrographic description and classification of dolostones. Carbonates and Evaporites 28, 447-456.

Chatalov, A. 2014. Contribution to the lithostratigraphy and sedimentology of the Iskar Carbonate Group (Lower-Upper Triassic) in the Elovitsa (Melyane) anticline, northwestern Bulagria. II. Sedimentology of the dolostones. Annuaire de l'Université de Sofia "St Kliment Ohridski", Faculté de Géologie et Géographie 104 (1), 5-42 (in Bulgarian, with English abstract).

Chatalov, A. 2017a. Anachronistic and unusual carbonate facies in uppermost Lower Triassic rocks of the western Balkanides, Bulgaria. Facies 63:24, doi: 10.1007/s10347-0170505-0

Chatalov, A. 2017b. Quartz arenites and laterites in the Moesian Group (Upper Triassic), northwestern Bulgaria: possible evidence for the effect of the Carnian Humid Episode. Geologica Balcanica 46, 3-25.

Chatalov, A. 2018. Global, regional and local controls on the development of a Triassic carbonate ramp system, Western Balkanides, Bulgaria. Geological Magazine 155, 641673.

Chatalov, A., Benatov, S. 2000. New data on the Godech lithostratigraphic unit (Middle Triassic) in the western Balkanides. Annuaire de l'Université de Sofia "St Kliment Ohridski”, Faculté de Géologie et Géographie 93 (1), 65-82 (in Bulgarian, with English abstract).

Chatalov, A., Benatov, S., Vangelov, D. 2001. New data about the holostratotype of the Babino Formation (Middle Triassic). Annuaire de l'Université de Sofia "St Kliment Ohridski”, Faculté de Géologie et Géographie 94 (1), 27-40 (in Bulgarian, with English abstract).

Chatalov, A., Stanimirova, T. 2001. Diagenesis of Spathian and Anisian dolomites from the Western Balkanides, Bulgaria. Neues Jahrbuch für Geologie und Paläontologie Monatshefte 2001, 301-320.

Chatalov, A., Stefanov, Y. 2013. Contribution to the lithostratigraphy and sedimentology of the Iskar Carbonate Group (Lower-Upper Triassic) in the Elovitsa (Melyane) anticline, Northwestern Bulgaria. I. Revisiting the lithostratigraphic scheme. Annuaire de l'Université de Sofia "St Kliment Ohridski”, Faculté de Géologie et Géographie 103 (1), 5-36 (in Bulgarian, with English abstract).

Chatalov, A., Stefanov, Y., Vetseva, M. 2015. The Röt-type facies of the Western Balkanides revisited: depositional environments and regional correlation. 31st International Association of Sedimentologists Meeting of Sedimentology, Abstracts, p. 115.

Chatalov, A., Vangelov, D. 2001. Storm-generated deposits in the Anisian (Pelsonian) limestones from the Western Balkanides. Review of the Bulgarian Geological Society 62, 11-23.
Chatalov, G. 1980. Two facies types of Triassic in the Strandza Mountain, SE Bulgaria. Rivista Italiana di Paleontologia e Stratigrafia 85, 1029-1046.

Chemberski, H., Vaptsarova, A., Monakhov, I. 1974. Lithostratigraphy of the Triassic variegated terrigenous-carbonate and carbonate sediments studied with deep drilling in Northwestern and Central North Bulgaria. Annual of DSO Geological Exploration 20, 327-341 (in Bulgarian, with English abstract).

Chen, J., Chough, S.K., Chun, S.S., Han, Z. 2009. Limestone pseudoconglomerates in the Late Cambrian Gushan and Chaomidian Formations (Shandong Province, China): softsediment deformation induced by storm-wave loading. Sedimentology 56, 1174-1195.

Chow, N., Longstaffe, F. 1995. Dolomites of the Middle Devonian Elk Point Formation, Southern Manitoba: intrinsic controls on early dolomitization. Bulletin of Canadian Petroleum Geology 43, 214-225.

Clari, P.A, Dela Pierre, F., Martire, L. 1995. Discontinuities in carbonate successions: identification, interpretation and classification of some Italian examples. Sedimentary Geology 100, 97-121.

Compton, J.S. 1988. Degree of supersaturation and precipitation of organogenic dolomite. Geology 16, 318-321.

Coniglio, M., James, N.P. 1988, Dolomitization of deep-water sediments, Cow Head Group (Cambro-Ordovician), western Newfoundland. Journal of Sedimentary Petrology 58, 1032-1045.

Corlett, H.J., Jones, B. 2012. Petrographic and geochemical contrasts between calcite- and dolomite-filled burrows in the Middle Devonian Lonely Bay Formation, Northwest Territories, Canada: implications for dolomite formation in Paleozoic burrows. Journal of Sedimentary Research 82, 648-663.

Demicco, R.V., Hardie, L.A. 1994. Sedimentary Structures and Early Diagenetic Features of Shallow Marine Carbonate Deposits. SEPM (Society for Sedimentary Geology), Atlas Series 1, 265 pp.

Dickson, J.A.D. 1965. A modified staining technique for carbonates in thin section. Nature 205, p. 587.

Dilliard, K.A., Pope, M.C., Coniglio, M., Hasiotis, S.T., Lieberman, B.S. 2010. Active synsedimentary tectonism on a mixed carbonate-siliciclastic continental margin: thirdorder sequence stratigraphy of a ramp to basin transition, lower Sekwi Formation, Selwyn Basin, Northwest Territories, Canada. Sedimentology 57, 513-542.

Folk, R.L. 1962. Spectral subdivision of limestone types. In: Ham, W.E. (Ed). Classification of carbonate rocks. American Association of Petroleum Geologists, Memoirs 1, 62-84.

Ganev, M. 1974. Stand der Kenntnisse über die Stratigraphie der Trias Bulgariens. In: Zapfe, H. (Ed.), Die Stratigraphie der alpin-mediterranean Trias: Simposium. Schriftenreihe der Erdwissenschaftlichen Kommission, Österreichische Akademie des Wissenschaften 2, 93-96.

Gawthorpe, R.L. 1987. Burial dolomitization and porosity development in a mixed carbonate-clastic sequence: an example from Bowland Basin, northern England. Sedimentology 34, 533-558.

Gebelein, C.D., Hoffman, P. 1973. Algal origin of dolomite laminations in stromatolitic limestones. Journal of Sedimentary Petrology 43, 603-613.

Gingras, M.K., Pemberton, S.G., Muelenbachs, K., Machel, H. 2004. Conceptual models for burrow-related, selective dolomitization with textural and isotopic evidence from the Tyndall Stone, Canada. Geobiology 2, 21-30.

Glumac, B., Walker, K.R. 2002. Effects of grand-cycle cessation on the diagenesis of Upper Cambrian carbonate depos- 
its in the southern Appalachians, USA. Journal of Sedimentary Research 72, 570-586.

Gnoevaya, N. 1965. Mineralisch-petrographische Charakteristik der Trias in Nordwest Bulgarien. Bulletin of the "Strašimir Dimitrov" Institute of Geology 14, 293-323 (in Bulgarian, with German abstract).

Gregg, J.M. 1988. Origins of dolomite in the offshore facies of the Bonneterre Formation (Cambrian), southeast Missouri. In: Shukla, V., Baker, P.B. (Eds), Sedimentology and geochemistry of dolostones. SEPM (Society for Sedimentary Geology), Special Publications 43, 67-83.

Gregg, J.M., Bish, D.L., Kaczmarek, S.E., Machel, H.G. 2015. Mineralogy, nucleation and growth of dolomite in the laboratory and sedimentary environment: a review. Sedimentology 62, 1749-1769.

Gregg, J.M., Sibley, D.F. 1984. Epigenetic dolomitization and the origin of xenotopic dolomite texture. Journal of Sedimentary Petrology 54, 907-931.

Ivanov, Ž. 2017. Tectonics of Bulgaria. Sofia University "St Kliment Ohridski”, Sofia, 317 pp. (in Bulgarian).

Jones, B., Oldershaw, A.E., Narbonne, G.M. 1979. Nature and origin of rubbly limestone in the Upper Silurian Read Bay Formation of Arctic Canada. Sedimentary Geology 24, 227-252.

Kaczmarek, S.E., Sibley, D.F. 2011. On the evolution of dolomite stoichiometry and cation order during high-temperature synthesis experiments: an alternative model for the geochemical evolution of natural dolomites. Sedimentary Geology 240, 30-40.

Kahle, C.F. 1965. Possible roles of clay minerals in the formation of dolomite. Journal of Sedimentary Petrology 35, 448-453.

Knaust, D., Curran, H.A., Dronov, A.V. 2012. Shallow-marine carbonates. In: Knaust, D., Bromley, R.G. (Eds), Trace fossils as indicators of sedimentary environments. Developments in Sedimentology 64, 705-750.

Korte, C., Kozur, H.W., Veizer, J. 2005. $\delta^{13} \mathrm{C}$ and $\delta^{18} \mathrm{O}$ values of Triassic brachiopods and carbonate rocks as proxies for coeval seawater and palaeotemperature. Palaeogeography, Palaeoclimatology, Palaeoecology 226, 287-306.

Kullberg, J.C., Oloriz, F., Marques, B., Caetano, P., Rocha, R.B. 2001. Flat-pebble conglomerates: a local marker for Early Jurassic seismicity related to syn-rift tectonics in the Sesimbra area (Lusitanian Basin, Portugal). Sedimentary Geology 139, 49-70.

Kupecz, J.A., Monanez, I.P., Gao, G. 1993. Recrystallization of dolomite with time. In: Rezak, R., Lavoie, D.L. (Eds), Carbonate microfabrics. Elsevier, New York, 187-194.

Kwon, Y.K., Chough, S.K., Choi, D.K., Lee, D.J. 2002. Origin of limestone conglomerates in the Choson Supergroup (Cambro-Ordovician), mid-east Korea. Sedimentary Geology 146, 265-283.

Li, F.B., Teng, F.Z., Chen, J.T., Huang, K.J., Wang, S.J., Lang, X.G., Ma, H.R., Peng, Y.B., Shen, B. 2016. Constraining ribbon rock dolomitization by $\mathrm{Mg}$ isotopes: implications for the 'dolomite problem'. Chemical Geology 445, 208-220.

Lumsden, D.N., Chimahusky, J.S. 1980. Relationship between dolomite nonstoichiometry and carbonate facies parameters. In: Dunham, J.B., Ethington, R.L. (Eds), Concepts and models of dolomitization. SEPM (Society for Sedimentary Geology), Special Publications 28, 111-121.

MacEachern, J.A., Bann, K.L., Pemberton, S.G., Gingras, M.K. 2007. The ichnofacies paradigm: high-resolution paleoenvironmental interpretation of the rock record. In: MacEachern, J.A., Bann, K.L., Gingras, M.K., Pemberton, S.G. (Eds), Applied ichnology. SEPM (Society for Sedimentary Geology), Short Course Notes 52, 27-64.
Machel, H.G. 1997. Recrystallization versus neomorphism, and the concept of "significant recrystallization" in dolomite research. Sedimentary Geology 113, 161-168.

Machel, H.G. 1999. Effects of groundwater flow on mineral diagenesis, with emphasis on carbonate aquifers. Hydrogeology Journal 7, 94-107.

Machel, H.G. 2004. Concepts and models of dolomitization: a critical reappraisal. In: Braithwaite, C.J.R., Rizzi, G., Darke, G. (Eds), The geometry and petrogenesis of dolomite hydrocarbon reservoirs. Geological Society, London, Special Publications 235, 6-63.

Macquaker, J.H.S., Taylor, K.G., Keller, M., Polya, D. 2014. Compositional controls on early diagenetic pathways in fine-grained sedimentary rocks: implications for predicting unconventional reservoir attributes of mudstones. American Association of Petroleum Geologists Bulletin 98, 587-603.

Mattes, B.W., Mountjoy, E.W. 1980. Burial dolomitization of the upper Devonian Miette buildup, Jasper National Park, Alberta. In: Zenger, D.H., Dunham, J.B., Ethington, R.L. (Eds), Concepts and Models of Dolomitization. SEPM Special Publications 28, 259-297.

Mazzullo, S.J. 1992. Geochemical and neomorphic alteration of dolomite: a review. Carbonates and Evaporites 6, 21-37.

Mazzullo, S.J. 2000. Organogenic dolomitization in peritidal to deep sea sediments. Journal of Sedimentary Research 70, 10-23.

McCrea, J.M. 1950. On the isotopic chemistry of carbonates and a paleotemperature scale. The Journal of Chemical Physics 18, 849-857.

McHargue, T.R., Price, R.C. 1982. Dolomite from clay in argillaceous or shale-associated marine carbonates. Journal of Sedimentary Petrology 52, 873-886.

Milliken, K.L. 2003. Late diagenesis and mass transfer in sandstone-shale sequences. In: Mackenzie, F.T. (Ed.), Sediments, diagenesis, and sedimentary rocks. Vol. 7. Treatise on geochemistry. Elsevier-Pergamon, Oxford, 159-190.

Mirsal, I.A., Zankl, H. 1985. Some phenomenological aspects of carbonate geochemistry: the control effect of transition metals. Geologische Rundschau 74, 367-377.

Morrow, D.W. 1978. Dolomitization of Lower Paleozoic burrow fillings. Journal of Sedimentary Petrology 48, 295306.

Murray, R.C., Lucia, F.J. 1967. Cause and control of dolomite distribution by rock selectivity. Geological Society of America Bulletin 78, 21-36.

Petrash, D.A., Bialik, O.M., Bontognali, T.R., Vasconcelos, C., Roberts, J.A., McKenzie, J.A., Konhauser, K.O. 2017. Microbially catalyzed dolomite formation: from near-surface to burial. Earth-Science Reviews 171, 558-582.

Petrash, D.A., Lalonde, S.V., Gingras, M.K., Konhauser, K.O. 2011. A surrogate approach to studying the chemical reactivity of burrow mucous linings in marine sediments. Palaios 26, 594-600.

Pollastro, R.M. 1993. Considerations and applications of the illite/smectite geothermometer in hydrocarbon-bearing rocks of Miocene to Mississippian age. Clays and Clay Minerals 41, 119-133.

Purser, B.H., Tucker, M.E., Zenger, D.H. 1994. Problems, progress, and future research concerning dolomites and dolomitization. In: Purser, B.H., Tucker, M.E., Zenger, D.H. (Eds), Dolomites. A volume in honour of Dolomieu. International Association of Sedimentologists, Special Publications 21, 3-20.

Rameil, N. 2008. Early diagenetic dolomitization and dedolomitization of Late Jurassic and earliest Cretaceous platform carbonates: a case study from the Jura Mountains (NW Switzerland, E France). Sedimentary Geology 212, 70-85. 
Rao, C.P. 1990. Marine to mixing zone dolomitization in peritidal carbonates: the Gordon Group (Ordovician), Mole Creek, Tasmania, Australia. Carbonates and Evaporites 5, 153-178.

Reineck, H.-E., Singh, I.B. 1980. Depositional Sedimentary Environments ( ${ }^{\text {nd }}$ revised and updated edition). Springer, Berlin-Heidelberg-New York, 551 pp.

Ren, M., Jones, B. 2017. Spatial variations in the stoichiometry and geochemistry of Miocene dolomite from Grand Cayman: implications for the origin of island dolostone. Sedimentary Geology 348, 69-93.

Rosenbaum, J., Sheppard, S.M.F. 1986. An isotopic study of siderites, dolomites and ankerites at high temperatures. Geochimica et Cosmochimica Acta 50, 1147-1150.

Rott, C.M., Qing, H. 2013. Early dolomitization and recrystallization in shallow marine carbonates, Mississippian Alida beds, Williston Basin (Canada): evidence from petrography and isotope geochemistry. Journal of Sedimentary Research 83, 928-941.

Sabbagh Bajestani, M., Mahboubi, A., Al-Aasm, I., MoussaviHarami, R., Nadjafi, M. 2018. Multistage dolomitization in the Qal'eh Dokhtar Formation (Middle-Upper Jurassic), Central Iran: petrographic and geochemical evidence. Geological Journal 53, 22-44.

Seilacher, A. 2007. Trace Fossil Analysis. Springer, BerlinHeidelberg, 226 pp.

Sharp, I., Gillespie, P., Morsalnezhad, D., Taberner, C., Karpuz, R., Vergés, J., Horbury, A., Pickard, N., Garland, J., Hunt, D. 2010. Stratigraphic architecture and fracture-controlled dolomitization of the Cretaceous Khami and Bangestan groups: an outcrop case study, Zagros Mountains, Iran. In: Van Buchem, F.S.P., Gerdes, K., Esteban, M. (Eds), Mesozoic and Cenozoic carbonate systems of the Mediterranean and the Middle East: stratigraphic and diagenetic reference models. Geological Society, London, Special Publications 329, 343-396.

Sherman, A., Narbonne, G., James, N. 2001. Anatomy of a cyclically packaged Mesoproterozoic carbonate ramp in northern Canada. Sedimentary Geology 139, 171-203.

Sibley, D.F. 1982. The origin of common dolomite fabrics: clues from the Pliocene. Journal of Sedimentary Research 52, 1087-1100.

Sibley, D.F., Gregg, J.M. 1987. Classification of dolomite rock textures. Journal of Sedimentary Petrology 57, 967975.

Śliwiński, M.G., Kozdon, R., Kitajima, K., Valley, J.W., Denny, A. 2016. Microanalysis of carbonate cement $\delta^{18} \mathrm{O}$ in a $\mathrm{CO}_{2}$-storage system seal: insights into the diagenetic history of the Eau Claire Formation (Upper Cambrian), Illinois Basin. American Association of Petroleum Geologists Bulletin 100, 1003-1031.

Sperber, C.M., Wilkinson, B.H., Peacor, D.R. 1984. Rock composition, dolomite stoichiometry, and rock/water reactions in dolomitic carbonate rocks. Journal of Geology 92, 609-622.

Srinivasan, K., Walker, K.R., Goldberg, S.A. 1994. Determining fluid source and possible pathways during burial dolomitization of Maryville Limestone (Cambrian), Southern Appalachians, USA. Sedimentology 41, 293-308.

Suchý, V., Rozkošný, I., Žák, K., Franců, J. 1996. Epigenetic dolomitization of the Př́dolí formation (Upper Silurian), the Barrandian basin, Czech Republic: implications for burial history of the Lower Paleozoic strata. Geologische Rundschau 85, 264-277.
Swart, P.K. 2015. The geochemistry of carbonate diagenesis: the past, present and future. Sedimentology 62, 1233-1304.

Taylor, T.R., Sibley, D.F. 1986. Petrographic and geochemical characteristics of dolomite types and the origin of ferroan dolomite in the Trenton Formation, Ordovician, Michigan Basin. Sedimentology 33, 61-86.

Török, A. 2000. Formation of dolomite mottling in the Middle Triassic ramp carbonates (Southern Hungary). Sedimentary Geology 131, 131-145.

Tronkov, D. 1960. Über die Stratigraphie der Trias im IskarDurchburch. Annuaire de la Direction Générale des Recherches Géologiques, série A 10, 131-153 (in Bulgarian, with German abstract).

Tronkov, D. 1968. Die Grenze Untere Trias - Mittlere Trias in Bulgarien. Bulletin of the Geological Institute, Series Palaeontology 17, 113-131 (in Bulgarian, with German and Russian abstracts).

Tronkov, D. 1973. Grundlagen der Stratigraphie der Trias im Belogradčik-Antiklinorium (Nordwest-Bulgarien). Bulletin of the Geological Institute, Series Stratigraphy and Lithology 22, 73-98 (in Bulgarian, with German and Russian abstracts).

Tronkov, D. 1976. Triassische Ammoniten-Sukzessionen im Westlichen Balkangebirge in Bulgarien. Comptes rendus de l'Académie bulgare des Sciences 29, 1325-1328.

Tronkov, D. 1981. Stratigraphy of the Triassic System in part of the Western Srednogorie (West Bulgaria). Geologica Balcanica 11, 3-20 (in Russian, with English abstract).

Tronkov, D. 1983. Mogila Formation (Lower-Middle Triassic) in Iskar gorge and Vratsa Mountain (west Stara planina). Geologica Balcanica 13, 37-52 (in Russian, with English abstract).

Tronkov, D., Enčeva, M., Trifonova, E. 1965. Stratigraphie des Triassystems in Nordwest Bulgarien. Bulletin of the "Strašimir Dimitrov" Institute of Geology 14, 261-292 (in Bulgarian, with German abstract).

Tzankov, Tz., Nedyalkova, L., Angelov, V., Aladjova-Hrischeva, K., Yanev, S., Haydutov, I., Sapunov, I., Tchoumatchenco, P. 1991. Geological map of Bulgaria. Scale 1:100 000. Vratsa map sheet. Geology and Mineral Resources Committee, Enterprise of Geophysical Survey and Geological Mapping.

Vasconcelos, C., McKenzie, J.A., Warthmann, R., Bernasconi, S.M. 2005. Calibration of the $\delta^{18} \mathrm{O}$ paleothermometer for dolomite precipitated in microbial cultures and natural environments. Geology 33, 317-320.

Veizer, J., Ala, D., Azmy, K., Bruckschen, P., Buhl, D., Bruhn, F., Carden, G.A.F., Diener, A., Ebneth, S., Godderis, Y., Jasper, T., Korte, C., Pawellek, F., Podlaha, O.G., Strauss, H. 1999. ${ }^{87} \mathrm{Sr} /{ }^{86} \mathrm{Sr}, \delta^{13} \mathrm{C}$ and $\delta^{18} \mathrm{O}$ evolution of Phanerozoic seawater. Chemical Geology 161, 59-88.

Warren, J. 2000. Dolomite: occurrence, evolution and economically important associations. Earth Science Reviews 52, 1-81.

Westphal, H., Head, M.J., Munnecke, A. 2000. Differential diagenesis of rhythmic limestone alternations supported by palynological evidence. Journal of Sedimentary Research 70, 715-725.

Zenger, D.H. 1996. Dolomitization patterns in widespread 'Bighorn Facies' (Upper Ordovician), Western Craton, USA. Carbonates and Evaporites 11, 219-225.

Zhu, S., Yue, H., Zhu, X., Sun, S., Wei, W., Liu, X., Jia, Y. 2017. Dolomitization of felsic volcaniclastic rocks in continental strata: a study from the Lower Cretaceous of the A'nan Sag in Er'lian Basin, China. Sedimentary Geology 353, 13-27. 